\title{
PRIMÓRDIOS DA REDE URBANA CEARENSE
}

\author{
Prof. Dr. Clovis Ramiro Jucá Neto \\ Universidade Federal do Ceará - Curso de Arquitetura e Urbanismo \\ Av. da Universidade, 2890 - Benfica CEP: 60.020-180 Fortaleza/CE, Brasil \\ Tel.: (85)3366-9602 - clovisj@uol.com.br
}

\begin{abstract}
RESUMO
O texto analisa os primórdios da formação da rede urbana cearense durante o século XVIII, destacando o papel do Estado Português e dos agentes locais envolvidos com a pecuária; que por sua vez deu sentido econômico à ocupação do território. Expulsas do litoral açucareiro nordestino, pela necessidade cada vez maior de terra para o plantio da cana de açúcar, o gado alcançou a Capitania cearense no final do século XVII através das estradas das boiadas. Em pontos estratégicos das estradas trilhas pelos vaqueiros, os portugueses fundaram as vilas do Ceará. Na escala regional, no início do século XIX, a Capitania estava totalmente interligada. Estes caminhos também levavam à Bahia, ao extremo oeste do território brasileiro e ao litoral nordestino brasileiro. A despeito, porém, de o território encontrar-se inteiramente interligado, o abastecimento da Capitania por uma produção interna de comestíveis era bastante rudimentar em decorrência da pequena produtividade e das grandes distancias entre as vilas.
\end{abstract}

Palavras-chave: Rede Urbana, Ceará, nordeste brasileiro.

\begin{abstract}
The text analyses the origin of the urban system formation in Ceará during the XVIII century, emphasizing the role of the Portuguese State and of its local agents involved with cattle raising, which gave an economic meaning to the territory occupation. Sent off from the sugar litoral of the Brazilian Northeast, due to the increasing necessity of soil in order to plant sugar cane, the cattle reached the captaincy of Ceará at the end of the XVII Century through the cattle roads. In strategic points of these roads, the Portuguese founded the villages of Ceará. In the regional scale, in the beginning of the XIX Century, the captaincy was completely interconnected. These roads also led to Bahia, located in the extreme west of Brazil, in the Northeastern coastline. However, although the territory was completely interconnected, the supply of the captaincy by an internal production of food was very rudimental because of the small productivity and of the huge distance between the villages.
\end{abstract}

Key words: Ceará, Urban system, brazilian northeast

\section{RÉSUMÉ}

Le texte analyse les origines de la formation du reseau urbain de Ceará pendant le XVIII siècle, en relevant le rôle de l'État portuguais e des agents locaux liés à l'élevage du bétail, activité qui a donné le support économique à l'occupation du territoire. Ce bétail a étteignit la Capitanie de Ceará a travers les routes de troupeau de boeuf à la fin du XVII siècle, aprés avoir eté chassé du litoral, ou il manquait de terrain pour la plantation de canne à sucre. En points stratégiques de ces routes, parcourrues par les vachers bouviers, les portuguais ont fondé les premières villes de Ceará. Sur le pont de vue de l'échelle regional, la Capitanie était completement interliée, au début du XIX siècle. Ces routes iraient aussi jusqu'à Bahia, à l'extreme ouest du térritoire brésilien et au litoral du nord-est. Malgré ces liaisons, l'approvisionement de la Capitanie, fait par la production interne des comestibles, était réalisé d'une façon très rudimentaire, en raison de la basse productivité e des grandes distances entre les villes.

Mots-clés: Ceará, reseau urbain, nord-est brésilien

\section{Introdução}

Embora a base da formação territorial brasileira estivesse posta após a União Ibérica, isto não significava que já estivesse consolidado o domínio de todo o espaço. Uma vasta zona de trânsito e visitação na hinterlandia, designada de sertão, ainda precisava ser definitivamente ocupada (MORAES, 2000, p.401). Entre as zonas de trânsito, encontrava-se o Ceará. Este artigo ${ }^{1}$ tem como objetivo revelar os primórdios da rede urbana na Capitania cearense, apontando para a lógica da apropriação do Estado português sobre o território, os caminhos da ocupação e sua espacialização. 
Sobre a ocupação do território cearense e a criação de suas vilas. A lógica da ocupação segundo o Estado Português5.6. A lógica da ocupação segundo o Estado Português

Concomitante à ocupação do Ceará seguindo as Estradas da pecuária - base econômica que atribuiu forma e conteúdo à Capitania - a lógica da fixação pelo Estado Português, com a criação de vilas no território cearense, não fugiu à lógica do "apetite territorial" que encontrou sua origem ainda na ampliação das rotas marítimas tanto no Índico como no Atlântico ${ }^{2}$ e alcançou, no século XVIII, a urgência da continuidade territorial, advogada por Alexandre de Gusmão ${ }^{3}$. Para Gusmão, o território português não estava restrito ao alcance de uma bala de canhão, mas a possibilidade de interligar todo o território até a região da Prata. Em cena a política de urbanização como uma etapa do processo de colonização (REIS FILHO, 1968).

Exatamente por se encontrar inexplorado até o final do século XVII, desabitado pelo "homem branco", a Capitania do Ceará não deixava de ser um "espaço novo" na perspectiva do colonizador", embora estivesse dentro dos limites das Tordesilhas. Era um espaço a ser ganho não de outro Estado, mas do agreste sertanejo, da população autóctone, e em alguns momentos, dos próprios sesmeiros.

A apropriação do Espaço cearense pelos portugueses incrementou, como em todo o restante da América Portuguesa, uma relação de dominação por meio do nexo sociedade e espaço físico ${ }^{5}$. Nesta perspectiva, a instalação e a consolidação ${ }^{6}$ do poder lusitano, na terra recém-conquistada, além de promoverem a implantação da autoridade do Estado Português no Ceará, trouxeram a dimensão da organização espacial do território e das vilas criadas para o centro de toda a vida econômica e social ${ }^{7}$ da Capitania.

\section{As justificativas para a criação de vilas no CearáAs justificativas para a criação de vilas no Ceará}

Na primeira metade do século XVIII, o Estado Português justificou a criação de vilas ${ }^{8}$ na Capitania cearense, vinculando uma idéia de justiça - atrelada à criação de um aparato burocrático mediador da ordem metropolitana e a "confusão" reinante no território cearense - a uma preocupação de ordem econômica, revelada pela ameaça dos prejuízos causados pela "desordem" manifesta. Nada mais justo para a expansão portuguesa do que aqueles povos se "aquietassem", pois desde o estabelecimento da linha imaginária das Tordesilhas, aquele solo the pertencia por direito.

Este processo de subordinação", aqui explicitado como "aquietação", procurou dissolver a resistência indígena ${ }^{10}$ à conquista e favorecer a fixação dos que vinham de longe - "embalados pelas perspectivas de desenvolvimento da região e a fim de melhor fortalecer as bases do poder real" (CASTRO, 2005, p.22).

Independentemente do real conhecimento das potencialidades econômicas da Capitania cearense, pois ainda se encontrava inexplorada no início do século XVIII, o que estava em pauta era a própria lógica da incorporação de qualquer terra aos domínios portugueses e a garantia da continuidade física de todo o território com a criação de vilas, além das possibilidades de explorações futuras - neste caso, a atividade criatória que se expandia em direção ao sertão, em busca de novas pastagens. Das vilas criadas partiriam no âmbito local - por meio das Ordens Régias que provinham, via Pernambuco, da distante Lisboa - as ações de "justiças" para "aquietação dos povos".

\section{o Ceará, a pecuária e a formação de um comércio interno na América Portuguesa}

Alcançando o Ceará, a pecuária manteve suas características. Continuou sendo uma atividade 
extensiva, extremamente fluida, com o crescimento vegetativo, com uma baixa produtividade e rentabilidade $^{11}$ - se comparada à produção açucareira - e uma reduzida capacidade de acumulação.

Os primeiros sinais da atividade comercial em torno da pecuária cearense unem as fazendas e os pequenos núcleos sertanejos cearenses com o seu litoral, com as feiras de gado da zona açucareira e com portos da Paraíba, Pernambuco e Bahia, de onde seguiam os couros em cabelo, os atanados e as solas para as cidades do Rio de Janeiro, Porto e Lisboa.

O principal mercado consumidor foi Pernambuco pela relativa proximidade geográfica e pelo fato de o Ceará ter sido politicamente seu dependente até 1799 (GIRÃO, 1984, p.82). Como a população era bastante escassa ${ }^{12}$ e de baixo poder aquisitivo, o excedente da produção seguia para o litoral açucareiro, suprindo as necessidades da Zona da Mata e do Recôncavo Baiano. Este excedente de carne verde, produzido nos sertões do nordeste e comercializado nas principais feiras e portos do litoral alterou, durante todo o século XVIII, o sentido único de subsistência da economia na Capitania cearense.

Por outro lado, as distâncias eram grandes e os percursos impiedosos. Nas grandes travessias do sertão para o abastecimento da zona do açúcar, perdiam-se muitas cabeças de gado provenientes do Ceará, muitas eram compradas pelos atravessadores e os que chegavam ao local de destino não possuíam, na maioria das vezes, um bom valor de venda pelos maus-tratos, em razão da falta de água e ausência de boas pastagens. Se já não bastassem, porém, os problemas resultantes das grandes distâncias e da adversidade climática sertaneja, ainda era obrigatório o subsídio do sangue (GIRÃO, 1984, 105).

\section{A técnica da salga cearense}

No final da década de trinta do século XVIII, a descoberta da técnica de salgar a carne ${ }^{13}$ no território cearense modificou, em parte, este panorama. Além de sua comercialização em pé nas feiras do Nordeste, o gado passou a ser negociado no litoral açucareiro, já abatido, tanto salgado como em forma de couro, proveniente dos portos do Ceará e do Rio Grande do Norte. A ativação do comércio marítimo com Pernambuco não apenas criou a alternativa mais rentável para economia cearense, garantindo a fixação de parte dos lucros na Capitania e, conseqüentemente, a possibilidade de inversão de capital em melhorias no espaço de suas vilas envolvidas com a salga da carne - mais especificamente a Vila de Santa Cruz do Aracati - como transformou o panorama do mercado interno no Nordeste da América Portuguesa.

A salga da carne incrementou, ainda, o fluxo comercial ${ }^{14}$ dentro da própria Capitania com as transações de compra e venda das boiadas, entre as vilas do sertão e as do litoral, onde se localizavam as salgadeiras. No século XVIII, o vale do Jaguaribe, a principal bacia hidrográfica do Ceará, presenciou intensa atividade comercial entre as vilas do Icó, no sertão, e a vila do Aracati, no litoral. Mais uma vez alterou-se o sentido exclusivo de subsistência da atividade econômica, agora com possibilidades de acumulação dentro do próprio território cearense.

As charqueadas do Ceará são explicadas como a alternativa econômica para o baixo rendimento da comercialização do boi em pé (NOBRE, 1977, p.63), como forma de os proprietários das fazendas de gado livrarem-se do subsídio do sangue (GIRÃO, 1962, p.122) e, ainda, como uma solução prática dos fazendeiros do litoral aracatiense concorrerem com os da ribeira do Icó, que se favoreciam da sua proximidade geográfica com as feiras de Pernambuco e da Paraíba (NOBRE, 1977, p.42).

\section{A importância da carne salgada cearense no mercado interno da América Portuguesa.}

Em 11 de maio de $1788^{15}$, o governador pernambucano, Capitão-General Dom Tomás José de Melo, enfatizou a importância do comércio de carne seca do Ceará para o mercado interno da América Portuguesa. Ele ordenou que, das oficinas do Aracati, Camocim e do Acaraú, viessem, todos os anos, 18 barcos de carne salgada ou "carne do Ceará". Doze barcas abasteceriam a praça de Pernambuco ao 
preço de 5.000 arrobas, resultando em um montante de 60.000 arrobas. As demais barcas somente seguiriam para outras capitanias (Bahia e Rio de Janeiro) após o próprio governador certificar-se de que não faltava aquele produto para a alimentação da população pernambucana.

O comércio de carne seca já havia inquietado, em 1764, os anseios lucrativos dos "homens de negócio" da Praça pernambucana. Eles propuseram a criação de uma Companhia de Comércio ${ }^{16}$ com os "portos do sertão" - ou seja, os portos do Rio Grande do Norte e do Ceará - onde transitavam de "trinta e duas até trinta e cinco" embarcações. O principal argumento era impedir a ruína dos comerciantes e criadores de gado do sertão e garantir-se o abastecimento de carne vermelha nos portos de Pernambuco, Bahia e Rio de Janeiro, pois a falta que havia de carne fresca no litoral decorria de não poderem ali chegar as "boyadas em razão das rigorosas secas que se esprementão nos sertões de donde vem os gados", fazendo com que tanto "os povos das praças" como as famílias dos engenhos e das fábricas não fossem "socorridos com carnes frescas, porque estas se arruinão". Já a carne salgada era "maiz cômoda e útil a toda a pobreza", porque não sofria durante o transporte e durava mais sem apodrecer.

Seria, portanto, conveniente a manutenção do fluxo de navegação com os "portos do sertão"-Assú e Mossoró, no Rio Grande e Aracati, Camocim, Acaraú e Itapajé no Ceará - onde se transportariam cerca de trinta mil cabeças de gado salgado para ser consumida, a maior parte no Recife, e o restante se venderia na Bahia e no Rio de Janeiro, ampliando o consumo interno de carne seca na América Portuguesa. Já o couro, parte seguia em cabelo para metrópole e a outra já curtida, na forma de sola.

Em 1787, Ouvidor do Ceará, Manuel Magalhães Pinto Avelar, ao escrever sobre a situação econômica da Capitania para a Rainha D. Maria $\mathrm{I}^{17}$, levantou o mérito da atividade comercial na estruturação do território cearense. Reconheceu que todas as suas vilas, excetuando Aquiraz, Fortaleza, Icó e a dos Índios, eram visivelmente "fillhas da propagação do comercio interior, e criadas desde o anno de 1740 para cá, em que o mesmo principiou-se a dilatar-se algum tanto neste pais".

\section{Os rendimentos da atividade criatória no território brasileiro.}

Reconhecendo a importância dos produtos ligados à pecuária para os rendimentos da América Portuguesa, Antonil (1963, p.98), em sua Cultura e Opulência do Brasil por suas Drogas e Minas, pediu que se fizesse "justo conceito das boiadas", pois os currais dos sertões da Bahia, de Pernambuco e das demais capitanias estavam repletos de bois e algumas de suas fazendas chegavam a ter de 6.000 a 20.000 cabeças de gado. Cada rês era vendida em Salvador por quatro ou cinco mil réis e os bois mansos por sete a oito mil réis; já no sertão baiano, especificamente em Jacobina, o preço caia para dois mil quinhentos e três mil réis. Também todos os rolos de tabaco que "se embarcão para qualquer parte, vão encourados"; e da Bahia seguem "ordinariamente cada anno pelo menos, vinte e cinco mil arrobas" e das "Alagoas de Pernambuco, duas mil e quinhentas" (Ibidem, p.96).

A sola rendia 201.800\$000, ocupando a quarta posição nas exportações da América Portuguesa. Já o rendimento do tabaco, enfardado em couro, era da ordem de 344.650\$000, ocupando a terceira posição daquilo que ia para Portugal. Nesta época, seguiam da Bahia para a Metrópole cerca de cinqüenta mil meios de sola que ao preço de $1 \$ 980$ réis resultava para o erário 99.000\$000; de Pernambuco, seguiam quarenta mil meios a $1 \$ 750$ réis, que importavam $70.000 \$ 000$; e já o Rio de Janeiro produzia vinte mil meios de sola, equivalente a $32.800 \$ 000$, com o preço de $1 \$ 640$ a unidade. A Bahia ficava com $45,4 \%$ das exportações, Pernambuco com $36,6 \%$ e o Rio de Janeiro e as demais capitanias sulinas, 17,9\%. Portanto, no início do século XVIII, oitenta e dois por cento da produção de sola era proveniente da região nordestina (ANTONIL, 1963, p. 98).

Na segunda metade do século XVIII, a pecuária foi a segunda fonte econômica para a América Portuguesa, na área de abrangência da Companhia de Comércio de Pernambuco e da Paraíba. Em forma de solas, couros em cabelo e atanados, deixou de ser uma atividade exclusivamente subsidiária e de subsistência. Estes produtos invadiram os porões dos navios, que partiam de Pernambuco e da Paraíba para Portugal. O volume transportado para os portos portugueses revela a importância da economia no 
comércio do Atlântico, fazendo Godinho (1990, p.489) reconhecer que as frotas do Nordeste brasileiro eram até certo ponto "frotas de coiro" 18.

\section{O movimento, nos portos da Paraíba e de Pernambuco, dos produtos oriundos da pecuária.}

Entre 1760 e $1778^{19}$, seguiram de Pernambuco e da Paraíba para a cidade de Lisboa e do Porto, 139.795 caixas de açúcar, além de considerável volume de couros provenientes da pecuária nordestina. Exportaram-se 993.659 unidades de couro em cabelo, 321.199 de atanados e 1.285.955 de meios de sola $^{20}$.

A despeito, porém, do maior volume de exportação dos derivados da pecuária, o seu valor de venda era, aproximadamente, duas vezes e meio menor que o valor de venda da produção açucareira, conforme a tabela de "Calculo das Exportações das Capitanias de Pernambuco e Paraíba para este Reino no anno de 1778 " ${ }^{21}$. Neste ano, embarcou-se para as cidades de Lisboa e do Porto, 8.600 caixas de açúcar branco. Ao todo, significaram 361.200 arrobas vendidas, que ao preço unitário da arroba de $2 \$ 500$ resultou em um montante de $903.000 \$ 000$. Este valor, unido ao do açúcar mascavo, a $1 \$ 800$ a arroba, representou um valor total de venda de $958.112 \$ 400$.

Entre os produtos da pecuária, somente os atanados eram calculados em arrobas com o valor de \$110, infinitamente inferiores ao do açúcar. A base de cálculo para os demais produtos era a unidade. $\mathrm{O}$ couro em cabelo foi vendido a $2 \$ 400$ a unidade, os meios de sola a $1 \$ 600$, e as vaquetas a $1 \$ 200$. O valor total das vendas dos couros e similares foi de $296.319 \$ 320$; ou seja, o açúcar representou 71,98\% do lucro e os produtos da pecuária $28,01 \%{ }^{22}$.

\section{Estimativa da contribuição cearense}

Em relação ao Ceará, em 28 de março de 1758, o Provedor da Fazenda da Capitania informou a D. José $\mathrm{I}^{23}$ que os dízimos cearenses não foram cobrados em "sinco ramos", mas somente nas quatro principais ribeiras: a do Ceará, a de Russas, do Acaracú e de Icó. Declarou, sem explicitar as razões, que não cobrou os da ribeira do "Curahayhu", que era distrito do Acaraú, conforme ordem do próprio Rei.

Naquela altura, ainda segundo o Provedor, o reduzido número de arrematadores dos contratos ${ }^{24} \mathrm{da}$ carne, já que não havia "fiadores desobrigados da Fazenda Real com capacidade de poderem ser", decorria do aumento dos dízimos, "principalmente das ribeiras do Icó, Russas e Acaraú”. Assim, sugeriu ao Rei - pois seria "útil”" para a fazenda real - que se descentralizassem a sua cobrança, dividindo aquelas principais ribeiras em mais ramos.

Os dízimos do Icó seriam cobrados em suas três freguesias, pois cada uma tinha a capacidade "pelas suas divisões de se rematarem separadamente". A primeira freguesia compreendia a própria vila, a segunda, a região das minas dos "Kariris Novos" e a terceira, o sertão dos Inhamuns. Russas seria dividida entre a freguesia da própria vila e a outra parte, na freguesia de Quixeramobim. Já no Acaraú, os dízimos deveriam ser cobrados, embora possuísse quatro freguesias, em duas partes. Uma que compreenderia a freguesia do Curahayhu "por toda a beira mar e suas prayas" e outra, que englobava o sertão daquele distrito.

Com isto, o funcionário régio visava não apenas a atrair os possíveis arrematadores como também ampliar os rendimentos das arrematações. Em 8 de julho de $1763^{25}$, D. José I respondeu ao dito provedor, concordando com as sugestões oferecidas.

Além das freguesias do Ceará, de Russas, do Icó e do Acaraú, já tinham sido cobrados, entre 1774 e 1778 na Capitania cearense, os dízimos nas freguesias de Quixeramobim, Coreaú, Cariris Novos e Inhamuns. No cômputo geral, as oito freguesias renderam um acréscimo de $56.701 \$ 900$ para os cofres da Coroa, totalizando 10,63\% dos rendimentos gerais da Capitania de Pernambuco e suas anexas; ou seja, apenas a sua décima parte ${ }^{26}$. 
Se Pernambuco foi responsável por $66,29 \%$ do aumento dos contratos reais, a diferença entre o Ceará e a Paraíba foi somente de $1,12 \%$ e do Ceará e o Rio Grande do Norte, de 2,04\%. Se, por um lado, confirma-se a já sabida supremacia da economia pernambucana, por outro lado, identifica-se uma equivalência de importância econômica entre as demais capitanias.

\section{Os lugares de maiores arrecadações no Ceará.}

Os $10,63 \%$ do aumento relativo aos rendimentos dos contratos cearenses para os cofres reais foram arrecadados nas diversas freguesias da capitania. Coube à de Icó, 30,31\%, à de Russas, 14,93\%, à de Inhamuns, $11,46 \%$, à de Coreaú, 10,91\%, à dos Cariris Novos, 10,40\%, à do Ceará Grande, $9,35 \%$, à do Acaraú, 7,10\% e a de à de Quixeramobim, 5,50\% ${ }^{27}$.

Russas e Quixeramobim pertenciam à Ribeira do Jaguaribe; e os Cariris Novos, o Icó e os Inhamuns à Ribeira do Icó. Ambas fazem parte da bacia do Jaguaribe, totalizando em toda a sua extensão 72,6\% da arrecadação geral da Capitania. As demais ribeiras correspondiam às bacias do mesmo nome.

Também o que receberam de dízimos dos diversos contratos o almoxarife Gerardo Marques da Costa para os anos de 1777, 1778, 1779, o almoxarife Pedro Rodrigues Correa, para o ano de 1782 e o almoxarife Pedro Barrozo para os anos de 1783, 1784, 1785 confirmam que os maiores rendimentos concentravam-se nas bacias do Jaguaribe, Acaraú e Coreaú ${ }^{28}$.

No triênio de 1777 a 1778, as cinco maiores arrecadações ocorreram, por ordem crescente de grandeza, nas freguesias do Acaraú, Russas, Icó, Quixeramobim e Seara. No ano de 1782, nas vilas de Sobral, Quixeramobim, Russas, Icó e Coreaú. No triênio 1783 a 1785, nas freguesias de Icó, Russas, Quixeramobim, Sobral e Serra dos $\operatorname{Cocos}^{29}$. As principais vilas setecentistas da Capitania cearense estavam exatamente nestas freguesias de maior arrecadação. Além da vila do Aracati, localizada na freguesia de Russas, e o Icó, a vila de Sobral começa a despontar nos últimos vinte cinco anos de século XVIII com uma importante vila na Capitania do Ceará.

\section{A fixação da autoridade portuguesa - A Ordem Régia de 13 de fevereiro de 1699A Ordem Régia de 13 de fevereiro de 1699}

Em 13 de fevereiro de $1699^{30}$, o Governador pernambucano Caetano de Melo e Castro recebeu ordens do Reino para "q'se crie uma villa no Ceará".

A Ordem Régia foi clara. Era necessário que se fizesse ou se implantasse a "justiça" para se evitarem “prejuízos”. Fazia-se urgente a eleição de oficiais de câmara e juízes ordinários, como as que já havia no Rio Grande do Norte e no sertão da Bahia, para “por este meio se evitarem muitos prejuisos q' até agora se experimentavam" os moradores do Ceará, pela falta de "modos de justiça" ${ }^{31}$.

\section{As vilas criadas na primeira metade do século XVIII}

A princípio, a Carta Régia de 13 de fevereiro de 1699 "significava dizer que a vila deveria ser implantada às margens do rio Ceará" ou seus arredores, pois na época e até o início do século XX, "o nome Ceará se referia em especial às terras adjacentes à ribeira do pequeno rio homônimo" restrito a vila. Contrariando as determinações régias, a vila foi fundada no Iguape, em 1701, mais de seis léguas a leste da foz do rio. Em 1706, foi transferida para aquela desembocadura e posteriormente para o entorno do forte de Nossa Senhora da Assunção, atual cidade de Fortaleza. Diante da "possibilidade de terem de enfrentar a soma dos poderes civis e militares com que uma vila no forte passaria a contar", os proprietários de terra da ribeira do rio Pacoti argumentaram com o governador de Pernambuco a transferência da vila para o sitio Aquirás, que a autorizou em 17 de junho de 1713 (CASTRO, 2005, p.22).

No dia 13 de abril de 1726, o Capitão-Mor do Ceará Manoel Francês fundou uma nova vila junto à Fortaleza de N. Senhora d'Assumpção, muito próxima a de Aquirás, declarando a sua importância para o aumento e defesa da Capitania. Estas razões foram, ainda, explicitadas nos documentos de criação da 
vila do Icó ${ }^{32}$ e do Aracati, também na primeira metade do século XVIII.

Em 6 de janeiro de $1735^{33}$, o Governador de Pernambuco Duarte Sodré Pereira escreveu a Dom João V, informando que o Ouvidor Geral da Capitania do Ceará Cardoso de Novaes Pereira lhe remeteu uma carta reconhecendo a necessidade de se criar uma nova vila na Capitania "no lugar a q' chamão de Icó", onde se encontrava a "Igreja Matriz do destricto". Para o governador, não só lhe "pareceu justo q" a haja pa administração da justiça mais he perciza pa a aquietação dos povos". O Conselho Ultramarino aprovou a solicitação em carta de 27 de Abril de $1735^{34}$. Já as discussões que antecederam à elevação do núcleo do Aracati à condição de vila em 1748 reconheciam a importância da presença tanto de um juiz ordinário como de tabelião da vila do Aquirás, nos períodos de maior movimento naquele porto quando havia "tal barafundas de descordias", como nos revela a Carta Régia de 8 de janeiro de $1743^{35}$.

\section{As vilas de índios na segunda metade do século XVIIIA vilas de índios na segunda metade do século XVIII}

Na segunda metade do século XVIII, como etapa do programa político e econômico de reestruturação do Estado Português, o Marques de Pombal ${ }^{36}$ implantou uma série de ações, visando a estabelecer a integridade e a defesa da hegemonia da Coroa em todos os seus territórios. Na América Portuguesa, foram inúmeras as ações ${ }^{37}$, entre as quais, incrementou o programa de instalação de vilas para procurar anular a dispersão reinante, ocupando e povoando definitivamente o território brasileiro.

$\mathrm{Na}$ Capitania do Ceará, as orientações pombalinas para elevação à condição de vila das aldeias de índios - Vila Real do Soure (1759) ${ }^{38}$, Vila Real de Arronches (1759) ${ }^{39}$, Vila Viçosa Real (1759), Vila Real de Messejana (1758), a Vila de Monte-mor o Novo da América (1764) e a Vila do Crato (1764) foram expressas na Carta Régia de 14 de setembro de $1758^{40}$ enviada ao governador e capitão-geral da Capitania de Pernambuco, Luiz Diogo Lobo da Silva.

A carta ordenava que fossem seguidas as diretrizes das leis de 6 e 7 de junho de 1755 e do Alvará de 8 de maio de $1758^{41}$, quando se restituiu a todos os índios que habitavam o Brasil a liberdade ${ }^{42}$ que já havia sido concedida aos índios do Maranhão. A de 7 de junho, além da liberdade, ordenou o estabelecimento dos silvícolas "na forma do governo temporal" porque assim seriam mais facilmente "atrahidos a receberem a fé e a se meterem no gremio da igreja". Eles seriam "governados pelos seus principais que houver por cada aldeã" e não mais pelos jesuítas. Esta Lei de 7 de junho também esclarecia que nas vilas seriam preferidos para os cargos de "juizes ordinários, vereadores e officiaes de justiça os índios naturaes d'ellas e de seus respectivos distritos".

Já o Alvará de 8 de maio de 1758, após confirmar tanto a "liberdade das pessoas e bens de raiz [...], como a liberdade do exercício da agricultura e do comércio, reforçou a importância de uma "forma de governo próprio para civilisal-os e attrahil-os por este único e adequado meio ao grêmio da santa madre igreja"; e por fim, reconheceu a utilidade de fazer as demais "leis geraes em benefício de todo o Estado do Brasil”. D. José I estendeu estas determinações régias a todos os índios que habitavam a América Portuguesa, exatamente como estava "expresso nas referidas leis sem interpretação, restricção ou modificação" para que eles fossem julgados como se julgavam os das capitanias do Grão Pará e Maranhão.

Com tudo isto, tão logo o governador Luis Diogo Lobo da Silva recebesse a carta de 14 de setembro, ele deveria restituir aos índios da Capitania a "a inteira liberdade de suas pessoas, bens e commercio".

Ainda em conformidade com este documento, as novas vilas passariam a ter os nomes dos lugares e vilas do Reino, "sem attenção aos nomes bárbaros que têm actualmente". Entre julho de 1759 e janeiro de 1760, a antiga aldeia da Ibiapaba passou a chamar-se Vila Viçosa Real; a aldeia da Caucaia, Vila Nova de Soure; a aldeia da Parangaba, Vila Nova de Arronches e a aldeia de Paupina, Vila Nova de Messejana. Em 1764, a missão de Palma recebeu o novo nome de Montemor-o-Novo d'América e a aldeia de Miranda de Vila Real do Crato. Seguindo as orientações das leis gerais, também presentes no Diretório, seria ainda estabelecida a administração municipal, conforme anteriormente anunciada; ou seja, "a forma de governo civil [...] na mesma conformidade que se acha praticado no Estado do Maranhão". 


\section{As demais vilas de branco criadas na segunda metade do século XVIIIAs demais vilas de branco criadas na segunda metade do século XVIII}

O argumento da dispersão e a idéia de "civilizar" a população, agrupando-os em vilas para melhor controlá-la, foi também usada para a criação das vilas de brancos espalhadas no território cearense. A ameaça à definitiva ocupação residia na dispersão reinante. Em 1773, foi fundada a Vila Real do Sobral; em 1776, a Vila Real de Granja; em 1789, a Vila de Campo Maior de Santo Antonio do Quixeramobim; em 1791, a Vila Nova Del Rei; em 1801, Vila de São Bernardo de Russas e, em 1802, a Vila de São João do Príncipe.

Em decorrência das "muitas queixas" provenientes "dos cruéis e atrozes insultos, que nos sertões" da Capitania de Pernambuco "tem commettido os vadios e os facinorosos", que vivem como "feras separadas da sociedade civil e commercio humano", o Rei de Portugal D. José I expediu, no dia 22 de julho de 1766, uma Ordem Régia ${ }^{43}$ obrigando a todos os que se achavam "vagabundos, ou em sítios volantes" nos ditos sertões que se acomodassem em "povoações civis" com mais de cinqüenta "fogos", com "juiz ordinário, vereadores e procurador do Conselho".

Aqueles que não se apresentassem, congregando-se e reduzindo-se a "sociedade civil nas povoações" seriam tratados como "salteadores de caminhos e inimigos communs", sendo "punidos com a severidade da lei". De acordo com aquela Carta Régia, seriam poupados somente os "rosseiros que com creados, escravos e fabrica" vivessem nas fazendas, os "rancheiros, que nas estradas publicas" se achassem estabelecidos em seus ranchos "para a commodidade dos viandantes em beneficio do commercio e da communicação" interna da Capitania; e ainda, os que fizessem parte das "bandeiras ou tropas que em corpo e sociedade útil e louvável voa aos sertões congregados em boa união para nelles fazerem novos descobrimentos". Ou seja, por um lado, seriam punidos todos os que se encontravam sem endereço fixo assaltando as estradas cearenses, e por tal comprometendo os rendimentos da Coroa; por outro, seriam poupados os que estivessem fixos e de alguma forma produzindo ou que estivessem servindo à Metrópole, comprometidos com a expansão territorial.

Dando continuidade ao projeto iluminista setecentista português, o Ouvidor Geral Dr. Manoel de Magalhães Pinto e Avellar de Barbedo reconheceu, no edital de convocação ${ }^{44}$ para a inauguração da vila de Campo Maior de 11 de maio de 1789, a utilidade e conveniência para o "bem comum da sociedade civil", para o "socego publico", para a "administração da justiça" e para o "real serviço" a criação da vila. Daí porque se devia recolher e congregar "todos os homens vadios e vagabundos" que viviam "afastandose da sociedade civil à maneira de feras" e que "vivem embrenhados pelo centro dos mattos virgens destes sertões, tendo em horror à união social e communicação das gentes". Estes "homens errantes e inoficiosos" seriam atraídos e obrigados a nela "viver, edificar e a trabalhar", civilizando-se e civilizando os "povos d'arredor", promovendo, assim, a “ordem e a felicidade publica”.

Também o Edital que comunicou à população da povoação de Tauá a sua elevação à condição de vila em 1802 (MOTA, 2001, p.113-114) enfatizou a importância de se atrair e obrigar a fixação dos homens, que ameaçavam a tranqüilidade daqueles sertões, através dos novos modos de viver, edificar e de trabalhar. Somente assim, poder-se-ia aplicar o "castigo aos facinorosos", promovendo a "felicidade pública", adiantando-se a "despresada e necessária agricultura"; aumentando-se por fim, a "comonicação e comercio interno destes Paizes". Por tais razões, o Ouvidor Geral José da Sylva Coutinho ordenou a ereção daquele povoado à condição de Vila de São João do Príncipe. No dia 13 de maio, o ouvidor procedeu "a criasão da dita nova villa", ordenando que "todas as pessoas da Nobreza e do Povo" do antigo distrito de Tauá fossem sem "excepção alguma asistir pessoalmente em referido dia a solemne e festiva" data.

\section{O lugar das "vilas de branco" cearenses nos caminhos das boiadas.}


A análise da situação geográfica das "Vilas de Brancos" fundadas no território cearense evidencia a sua localização como estratégica para a produção, reprodução e circulação da atividade da pecuária. Elas se encontravam no cruzamento das estradas dos vaqueiros, nos locais de boas pastagens e na foz dos principais rios da Capitania cearense: os rios Jaguaribe, Acaraú e Coreaú. Pelo local das vilas, confirmase o interesse português pela atividade produtiva. Apreende-se que a Coroa possuía um conhecimento prévio da área e que a estratégia metropolitana foi a fixação em pontos do território favoráveis para o pouso, a meio caminho dos núcleos existentes, favoráveis ao abate, fabricação e comercialização de derivados da pecuária - o couro e a carne salgada - assim como do boi em pé.

\section{As estradas coloniais do Ceará. As estradas coloniais do Ceará.}

As principais estradas dos boiadeiros foram a Estrada Velha, Estrada Geral do Jaguaribe, a Estrada Nova das Boiadas, a Estrada das Boiadas, a Estrada Camocim-Ibiapaba, a Estrada Crato Oeiras, a Estrada Crato Piancó (figura 1).

No final do século XVII, a Estrada Velha ligava Recife ao Maranhão pelo litoral (STUDART FILHO, 1937, p.18). A Estrada Geral do Jaguaribe partia de Aracati, principal porto da Capitania, descia o rio Jaguaribe, passava em Russas e Icó e seguindo o rio Salgado ultrapassava a chapada do Araripe para alcançar os sertões do Pernambuco em direção à Bahia. Foi a mais importante via de circulação do Ceará no século XVIII, por onde eram levadas as mercadorias para o sertão, vindas de Aracati, provenientes das demais capitanias. Por ela também eram carregados os produtos das salinas cearenses para as regiões do rio São Francisco. Em direção ao Aracati seguia toda a produção do vale do Jaguaribe que "consistia quase unicamente em couros salgados e espichados e alguma pellica das que se trabalhavam em todo o sertão cearense" (Ibidem, p.29) e as boiadas que seriam salgadas nas oficinas de charque no litoral e transportadas em embarcações, a maioria eram sumacas, para Recife, Salvador e Rio de Janeiro. Pelo rio Jaguaribe, Icó e Aracati - as duas principais vilas do Ceará no século XVIII - mantiveram um intenso comércio, inicialmente com o gado e posteriormente, no século XIX, com o algodão.

A Estrada Nova das Boiadas ligava o vale do rio Acaraú, no Ceará, e o Piauí à Paraíba, pelo Ceará. Vindo da direção da Paraíba, passava por Pau-dos-Ferros, ultrapassava o rio Jaguaribe na altura da atual cidade de Jaguaribe, seguia pelo riacho do Sangue, cruzava o rio das Pedras, chegava ao rio Banabuiú e encontrava o rio Quixeramobim para alcançar a cidade de Quixeramobim. De lá, um ramal seguia para Crateús $^{45}$, entrando no Piauí pelo rio Poti. Outro ramal partia para Sobral seguindo para o porto de Acaraú, na bacia do rio Acaraú e em direção a Granja, rumo ao porto de Camocim, na bacia do rio Coreaú. Depois de Pau-dos-Ferros, no Rio Grande do Norte, encontrava a Estrada das Boiadas, na Paraíba, e seguia para a cidade de Recife (STUDART FILHO, 1937, p.30).

A Estrada das Boiadas vinha do médio Parnaíba em direção a Oeiras ${ }^{46} \mathrm{e}$ a atual Valença, ambas no Piauí; passava por Tauá, seguia o rio Jaguaribe até Icó, quando, alcançando a Paraíba, seguia por Souza, Pombal, Patos, Campina Grande, Ingá, Mogeiro e Itabaiana. De Itabaiana partia ou em direção a João Pessoa via Pilar e Santa Rita, ou em direção ao porto de Recife e Olinda, cruzando Pedra do Fogo, Itambé e por fim Goiana e Igarassu, em Pernambuco. De Tauá, podia-se alcançar a Estrada Nova das Boiadas. Pela Estrada da Boiadas eram abastecidos tanto os matadouros e as oficinas de charque do litoral, seguindo pela Estrada Geral em direção ao Aracati, como as feiras de gado em Campina Grande, Itabaiana, Pedra do Fogo e Itambé, na Paraíba, e Goiana e Igarassu, em Pernambuco. Dela também se serviam os fazendeiros do sertão para refazer seus gados, nas pastagens do rio Parnaíba, após as longas estiagens (STUDART FILHO, 1937, p.31).

A Estrada Camocim-Ibiapaba ligava Viçosa do Ceará, na serra da Ibiapada, a Granja e ao porto de Camocim pela bacia do Coreaú. Quixeramobim interligava-se, ainda, com os sertões da atual Santa Quitéria pela Estrada da Caiçara. Do Crato, partia-se tanto para Oeiras - Estrada Crato-Oeiras - via Campos Sales e Picos pelos vales férteis do Araripe, como para Piancó - Estrada Crato-Piancó alcançando Patos, na Estrada das Boiadas, já na Paraíba (STUDART FILHO, 1937, p.35-39). 

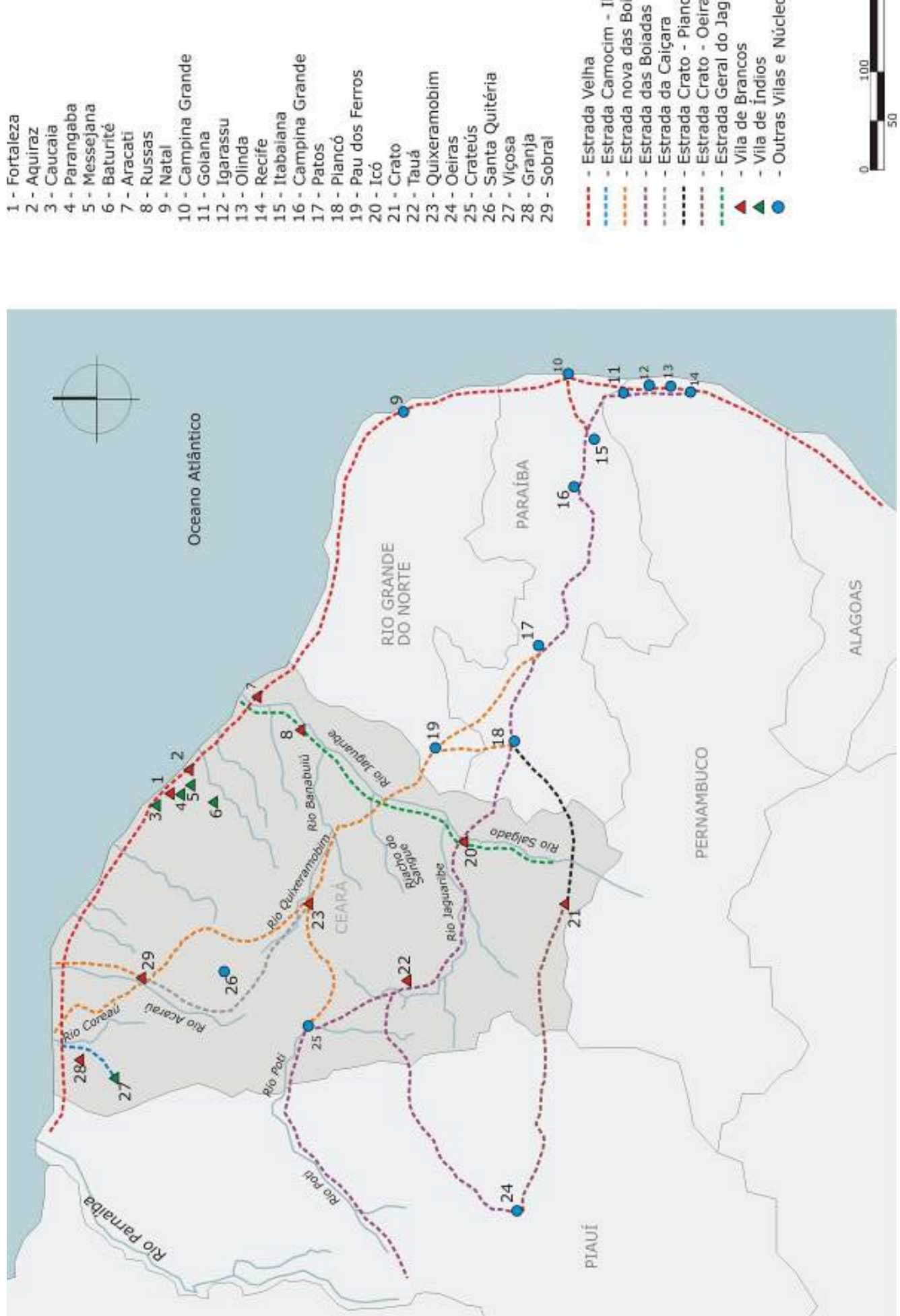

Figura 1. As estradas das boiadas. Fonte: Mapa elaborado pelo autor, a partir das informações contidas no texto Vias de communicação do Ceará colonial de Studart Filho (1937). 
Até os primeiros anos do século XIX, com exceção de Aquiraz (1713) e Fortaleza (1726), localizadas no litoral, as demais vilas de branco fundadas no território cearense localizavam-se em pontos estratégicos para a circulação do gado nas estradas das boiadas (figura 77). Tratamos de Icó (1736), Aracati (1748), Sobral (1773), Granja (1776), Quixeramobim (1789), Russas (1801) e Tauá (1802).

Aracati localizava-se na foz do rio Jaguaribe, para onde seguia a Estrada Geral do Jaguaribe. Quixeramobim localizava-se no cruzamento das estradas que vinham de Granja, Sobral, Crateús, de Santa Quitéria e da Paraíba. Sobral ligava o sertão central com o litoral noroeste da Capitania. De Tauá, podia-se seguir tanto para Oeiras, no Piauí, passando por Crateús, como para Icó. Russas estava na estrada geral do Jaguaribe e Icó. Situada no cruzamento desta com a Estrada Nova das Boiadas, comunicava-se diretamente com o Piauí, com a Paraíba e com Aracati, no litoral cearense.

A vila do Aracati foi o principal porto do Ceará durante o século XVIII. Em seu espaço, localizavamse as principais oficinas de charque do período. Antes mesmo da elevação à condição de vila, comercializavase de "vinte a vinte cinco mil bois" para a produção de carne seca. Na segunda metade do século XVIII, no espaço da vila podia ser encontrado tanto o animal vivo como a carne salgada e ainda "couro de bois salgados, vaquetas, couro de cabra e pelicas brancas". Anualmente, saíam do porto de Santa Cruz do Aracati cerca de 25 a 30.000 couros salgados, 50 a 60.000 meios de sola e "vaquetas", 30 a 35.000 couros de cabra e 2 a 3.000 pelicas (ALMEIDA, 1887, p.85).

Icó foi o mais importante ponto de escoamento, no sertão, da produção cearense. Para a vila seguiam boiadas de todas as estradas e partiam outras tanto para o Aracati como para as feiras da Paraíba e de Pernambuco. Os fazendeiros localizados nas proximidades do Icó possuíam uma vantagem sobre os demais da Capitania do Ceará por estarem próximos das feiras de Pernambuco e da Paraíba. "Essa concorrência interna tornava-se particularmente incômoda para os habitantes do médio e baixo Jaguaribe que também tinham na pecuária os seus meios de vida, pois, de outro modo não lhes seria possível efetivar a posse das vastas sesmarias e delas obter o sustento" (NOBRE, 1977, p.42). Quixeramobim, a meio caminho da Estrada Nova das Boiadas, "com suas ricas pastagens, era o único ponto onde as reses derreadas pela canícula e pela fome podiam refazer-se na longa travessia" (STUDART FILHO, 1937, p.33). Granja localizava-se na bacia do Acaraú, a segunda mais importante do território, próximo ao porto de Camocim. Sobral garantia o contato entre o sertão e o porto do Acaraú, através de Granja (GIRÃO, 2000, p.179).

\section{A capitania cearense, suas vilas e povoações. 6.6. A capitania cearense, suas vilas e povoações no início do século XIX - $O$ território interligado}

A princípio, a distribuição das sesmarias pouco alterou o espaço territorial cearense. Tratou-se de uma ocupação eminentemente rarefeita, caracterizada por extrema dispersão. A base desta dispersão rural foi o próprio sistema de distribuição das terras. As suas sedes, as fazendas de gado espalhadas pelo sertão, guardaram nos primeiros anos de colonização uma independência quase que absoluta entre si. Esta autonomia era decorrente tanto da auto-suficiência da produção como das grandes distâncias entre elas. A dinâmica extensiva da pecuária sertaneja também corroborou este caráter dispersivo. Por outro lado, a autonomia das fazendas de gado implicou a inexistência de uma rede de fazendas, dificultando um sistema de trocas de mercadorias entre os fazendeiros.

A ativação do comércio e o processo de centralização administrativa com a fundação das vilas criaram as bases para a futura rede urbana do território, alterando lentamente - no decorrer do século XVIII e início do século XIX, após o declínio da pecuária e já com os primeiros sinais da produção algodoeira - o quadro de dispersão. Não foi capaz, porém, de promover melhorias qualitativas em seus espaços pela falta de investimento de técnica e de capital.

Em primeiro lugar, foi a pecuária que atribuiu forma e conteúdo para o espaço territorial da Capitania e de suas vilas. As especificidades espaciais do território cearense foram características intrínsecas de seu processo de colonização, que teve como força motriz, asseguradora do projeto político lusitano de ocupação 
do sertão nordestino da América Portuguesa, a expansão da atividade criatória. Já sabemos que as vilas foram fundadas em pontos estratégicos para a atividade econômica. Em segundo lugar, a baixa capacidade de acumulação local e o pouco investimento português originaram uma pequena inversão de capital nas intervenções no espaço do território e das vilas do Ceará.

\section{O papel da pecuária no sertão e no litoralO papel da pecuária no sertão e no litoral}

O primeiro ponto nos leva de imediato para uma questão de escala, onde não se pode deixar de perscrutar os papéis específicos e complementares da atividade econômica, tanto para o sertão como para a América Portuguesa, e, ainda, para a totalidade do Império. Também não nos podemos esquecer de que, por todo o século XVIII, a Capitania do Ceará foi politicamente dependente da Capitania pernambucana.

Para a economia política portuguesa, durante a ocupação do sertão nordestino, a importância da pecuária impôs-se mais pela inserção do território sertanejo na lógica mercantilista da Coroa como garantia de uma continuidade territorial que confirmasse a fixação lusitana em todo território daAmérica Portuguesa, do que pelos baixos rendimentos da atividade, embora estes não tenham impedido que Godinho (1990) reconhecesse, em certa medida, as frotas do açúcar como verdadeiras frotas de couro.

Exatamente pelos fluxos das boiadas, a atividade comercial desenvolvida em torno da economia pecuarista alcançou os fluxos do Atlântico, estabelecendo uma conexão econômica entre o sertão, a zona açucareira, a Metrópole e a África - com exportação do tabaco - via portos do litoral nordestino e viceversa. Esta conexão só foi possível porque distâncias foram vencidas, caminhos foram abertos pelos vaqueiros e vilas fundadas em pontos estratégicos dos fluxos que se estabeleciam. Estes caminhos interligaram diversos núcleos pelo sertão adentro e levaram os produtos da pecuária ao litoral, para depois seguir em forma de couro e similares para a Metrópole, via portos de Pernambuco e Paraíba. Eles foram os verdadeiros vetores da ocupação e do povoamento da região a oeste do açúcar, responsáveis pela integração territorial de todo o Nordeste, e deste com o restante da América Portuguesa.

Se, porém, o criatório não deixou de ser uma atividade secundária e de subsistência para o mundo açucareiro da região do massapê, os seus derivados - o couro em cabelo, solas e atanados - oriundo do sertão ou mesmo manufaturados no litoral pernambucano, não deixaram vazios os porões das embarcações portuguesas nos primeiros trinta anos da segunda metade do século XVIII, ocupando o segundo lugar no conjunto das exportações da Companhia de Comércio de Pernambuco e da Paraíba.

Para o Ceará, ou para o sertão nordestino, a pecuária deixou de ser uma atividade acessória da economia açucareira. Desde sempre foi a principal ou a única atividade econômica, com possibilidades lucrativas, embora com uma reduzida produtividade e um pequeno rendimento, e, conseqüentemente, baixo poder de acumulação. Não foi, portanto, uma atividade secundária. Se foi subsidiária do açúcar no longínquo litoral, a atividade comercial das boiadas, a manufatura e a comercialização da carne salgada e dos couros e similares a conformaram como uma atividade essencial para o desenvolvimento da Capitania cearense durante todo o século XVIII.

A economia deixou de ter para escala do sertão o caráter único de subsistência que lhe foi atribuída na zona do açúcar, gerando um comércio interno na América Portuguesa, que, mesmo com a baixa capacidade de acumulação, foi capaz de gerar interesses econômicos metropolitanos sobre o território, impulsionando o movimento expansionista e, principalmente, fundamentando economicamente o sentido político de fixação do poder régio na Capitania cearense. Contudo, que em sua maior parte os rendimentos oriundos da pecuária cearense fixaram-se no litoral açucareiro e não no Ceará.

A produção de carne seca e de couro tornou complexa a trama das relações comerciais a partir da segunda metade do século XVIII. Por um lado, incrementou o comércio marítimo com Pernambuco, aumentando por sua vez a circulação dos produtos do Ceará, por outro, inaugurou uma divisão do trabalho dentro da própria atividade, que espacialmente se configurou na Capitania cearense com a especialização 
técnica do litoral, como área de produção e comercialização da carne salgada, e do sertão, como zona de produção extensiva, que, por sua vez, abastecia tanto as salgadeiras como as feiras pernambucanas, paraibanas e baianas.

Inaugurando densidades funcionais e técnicas diferenciadas entre as zonas sertanejas e litorâneas, a complexidade da economia estabeleceu graus de importância diferenciados tanto para os circuitos internos da atividade comercial como para o espaço das vilas propriamente dito. Estabelecidas hierarquias diferenciadas no complexo em formação, diferenciado também foi o grau de investimento de capital e técnica na adequação da espacialidade de cada vila às necessidades emergentes das transações comerciais.

O investimento passou a ser proporcional à importância e ao papel desempenhado pelo núcleo na trama dos caminhos dos boiadeiros. Exatamente estas diferenciações no grau de investimento de técnica e capital, decorrente da importância diferenciada dos diversos locais na Capitania para a atividade comercial - ou seja, para os interesses econômicos e políticos da Metrópole - caracterizaram a heterogeneidade do espaço da Capitania.

Ainda nesta direção, a condição de subsistência da pecuária viu-se ainda mais alterada nos lugares onde os fluxos da atividade comercial e de produção do couro e similares ofereciam capacidade de maiores rendimentos. Evidentemente, no ecúmeno do couro sertanejo, houve regiões onde a atividade da economia não largou o seu papel único de subsistência.

Em pleno sertão e no litoral cearense, foram elevados à condição de vila os principais núcleos da Capitania que se desenvolveram em torno da atividade criatória. A escolha não foi aleatória. Pelo que já foi dito, o que a norteou foram as potencialidades de cada lugar para a atividade; ou seja, o interesse político na fixação, na apropriação do território cearense, encontrou nos lugares propícios ao desenvolvimento do criatório o fundamento econômico para o estabelecimento das fazendas de gado, que deram origem aos primeiros núcleos e estes às futuras vilas no território. Excluindo-se Aquiraz, Fortaleza e as vilas de índios, as demais povoações escolhidas encontravam-se em pontos estratégicos para a produção e circulação dos produtos da atividade criatória. $O$ fato, porém, de aquelas vilas não estarem diretamente associadas à atividade comercial não significa que possam ser excluídas do exercício de compreensão do espaço da civilização do couro na Capitania do Ceará, pois desempenhavam outras funções indispensáveis para trama das relações. No geral, as vilas achavam-se nos cruzamentos dos caminhos das boiadas, na foz dos rios - zonas portuárias - em suas margens, ou, ainda, próximas às zonas propícias para a agricultura, na maioria das vezes em regiões serranas ou em suas proximidades.

\section{0 investimento de técnica e de capital como índice do interesse econômico e político português das vilas cearenses $O$ investimento de técnica e de capital como índice do interesse econômico e político português das vilas cearenses}

Aqui alcançamos o segundo ponto. O volume de investimentos na adequação do espaço das vilas cearenses aos interesses mercantis era coincidente com as suas maiores ou menores capacidades de acumulação dentro da Capitania, manifestando o grau de importância de cada vila na rede em formação. Além disso, o interesse relativo do lugar geográfico do Ceará para Portugal - se comparado com o litoral açucareiro, com a zona de mineração ou as fronteiras da Amazônia e do sul da Colônia - e a baixa capacidade de acumulação da economia, foram determinantes para o reduzido investimento de técnica e de capital na urbanização da Capitania.

No conjunto das vilas fundadas, as vilas do Aracati, Icó e Sobral - esta, no último quartel do século XVIII - destacam-se na rede urbana criada em torno da atividade da pecuária, por suas posições estratégicas no território. A primeira como o principal porto do Ceará, exportador da carne salgada e do couro, e as outras duas, por suas posições privilegiadas no sertão, no cruzamento das principais estradas dos boiadeiros. O Icó acha-se a meio caminho entre o Piauí e as feiras pernambucanas e paraibanas, e Sobral, a meio caminho entre a Ibiapada e o rio Jaguaribe, nas proximidades dos portos do rio Acaraú e Coreaú. Às demais vilas, Silva Paulet (1898), em sua Descripção Geografica Abreviada da Capitania 
do Ceará, atribui uma imagem de ruína no início do século XIX.

Aquiraz estava "inteiramente arruinada e sem comercio". A vila de Fortaleza, capital da capitania, era pobre, possuía uma Casa de Câmara arruinada, não possuía cadeia e seu "comercio de pouco vulto, ainda que o porto é soffrivel, [...] não há uma só caza de sobrado, e as térreas são muito inferiores". Icó era "termo mais povoado e civilizado da comarca e a villa de muito comércio". Aracati era "a mais opulenta da capitania [...] e aonde se acham cazas de sobrado; o que é devido a ser o ponto de embarque das produções dos algodões e solas do seo termo, [...] é o porto de desembarque dos gêneros, que de Pernambuco vem para este lado da capitania [...] Augmentou-se esta villa rápidamente em relação ás outras, mas acabou-se o motivo". Soure possuia "caza de câmara e cadeia, e nenhum patrimônio. Tem freguezia privativa. Contém 73 cazas, 44 sem portas nem janellas arruinadas, e 3 por acabar". A vila "seria melhor extinguil-a". Mecejana possuia "uma caza de câmara e cadeia, alguma plantação [...] Tem a villa 59 cazas, 17 por acabar sem portas, 15 arruinadas, 7 de homens brancos e 17 em estado de habitação, todas insignificantes. [...] Parece que seria melhor extinguir [...] e unir a povoação à villa de Fortaleza". A Vila do Crato era "a mais produtiva por estar nas fraldas da Serra-Grande, ahi denominada Araripe, aonde há muitas vertentes, mais ou menos abundantes. [...] Há n’esta 11.740 habitantes [...] Não tem caza de câmara; tem uma cadeia principiada". Arronxes estava "arruinada", tinha " 25 cazas, 13 de Índios, e 12 de extra-naturaes, e só 13 cazas estão em estado de habitação [...]. Seria melhor unil-a á villa de Fortaleza. Vila Viçosa Real não tinha "caza de câmara, nem cadeia, nem patrimônio o concelho, e nem se pode imaginar princípios de que provenha, porque não tem comercio algum. A Vila possuia "148 cazas, das quaes 123 são cobertas de palha; a maior parte [...] arruinadas". Monte-mor-o-Novo não tinha "caza de câmara, nem cadeia, nem conselho patrimônio", "84 cazas muito arruinadas, muitas cobertas de palha, e muito insignificantes". Sobral tinha "caza de câmara e uma cadeia por acabar. O conselho tem de renda annualmente $400 \$ 000$. [...] O commercio de exportação reduz-se a 70.000 meios de sola, que annualmente se navegam para Pernambuco; o mais é gado. Não produz algodão; aonde se colhe que a vila não é de importância, que se lhe pretende dar". Havia "na villa uma única caza de sobrado. Tanto a vila de Granja como o seu termo é pouco povoado. Não possuia "caza de câmara, nem cadeia, nem o conselho patrimônio, nem objetos de que se faça. O commercio é muito pequeno". Vila do Campo não tinha "caza de câmara nem cadeia, e nem patromonio para se fazer. Não tem o objecto de comercio sinão alguma sola; e mui pouca agricultura há no termo, porque as serras são muito secas". Vila Nova de EI Rei era "pobríssima [...] Não tinha caza de câmara nem cadeia e nem o conselho patrimônio; e nem de que se possa fazer. Possuia " 48 cazas de taipa e arruinadas". Vila de São Bernardo não tinha "caza de câmara nem cadeia, nem o conselho patrimônio". Villa de São-João do Príncipe possuía "55 cazas de telha van, muito baixas e arruinadas". Não tinha "caza de camara, nem cadeia" e "falta patrimônio ao conselho".

Excetuando-se o Icó, o Aracati e, em certa medida, Sobral, as demais vilas ou achavam-se arruinadas, ou com pouco comércio ou, ainda, sem nenhum patrimônio.

\section{Os primórdios da rede urbana.}

Na escala regional, no início do século XIX, o Ceará se encontrava todo interligado por estradas por onde circulavam as boiadas, resistentes à seca de 1793 e seus derivados, o algodão que se tornou a principal fonte econômica da Província cearense por toda aquela centúria e todos os demais produtos que abasteciam as vilas (figura 2). Estes caminhos também levavam à Bahia, ao extremo oeste do território brasileiro e ao litoral nordestino brasileiro (figuras 3, 4 e 5)

Entre as medidas apontadas, estava incentivo à agricultura, contudo, reconhece que ele só teria sentido com o trabalho de abertura e conserto das estradas da Capitania. O Ouvidor argumenta que os lucros poderiam ser maiores se elas, em sua maior parte, não se encontrassem "impraticáveis a homens de Cavallo, a Carros, e bestas Carregadas porque nunca virão beneficio de Homem”. De outra maneira, garantir-se-ia melhor fluidez da atividade comercial se não fosse "a deficuldade, trabalho, e vagar das 
conduçoens", fazendo com que todos os "gêneros do pais, que se exportão para o Reino", alcançassem um melhor preço. As estradas deveriam unir os sertões aos portos do litoral em "beneficio do Comercio Nacional activo" para o aumento dos lucros das praças de Lisboa e do Porto; ou seja, o argumento era que se mais facilmente os produtos locais pudessem ser consumidos por um maior numero de pessoas, alcançando os mais diversos pontos da América Portuguesa e a própria Metrópole, os rendimentos do Ceará aumentariam. Com abertura de novas estradas, as regiões até então inacessíveis poderiam ser beneficiadas e seus produtos comercializados. Como exemplo, o Ouvidor cita a serra da Ibiapaba, de onde se poderia colher de 15 ou 20 mil arrobas de algodão e nenhuma vantagem se tirava em decorrência do estado das estradas.

Em 1787, a importância de fazer o Ceará interligado por estradas fora levantada pelo Ouvidor do Ceará, Manuel Magalhães Pinto Avelar, em carta à rainha D. Maria I relatando a situação econômica da Capitania ${ }^{47}$. Defensor da autonomia econômica e política cearense em relação a Pernambuco (PINHEIRO, 2005), o Ouvidor propõem uma série de medidas para aumentar os rendimentos cearenses, enaltecendo os produtos locais, e justificar sua defesa ante o Conselho Ultramarino.

Além de regiões completamente isoladas, o lastimável estado em que se encontravam as estradas da Capitania agravava ainda mais a situação. Em sua maioria, os caminhos tornavam-se impraticáveis nos períodos chuvosos, quando os "pequenos regatos e torrentes, que no tempo da seca não levam agoa alguã [...] desbordão de tal forma, e se tornão profundos, e Caudalozos que se fazem absolutamte invadivens" impedindo toda a "comunicação e passagem entre as vilas", interrompendo por alguns meses o "comércio interior do pais". Como solução, o Ouvidor propunha a construção de pontes estreitas - "o que já em alguãs partes se tem feito" - ou uso de jangadas para serviço dos passageiros.

Neste quadro, alguns anos antes, em 1783, em sua Noticia Geral da Cappitania do Ceará Grande, o Governador Montaury dá conta de uma de rede urbana formada por sete vilas de Brancos, cinco vilas de Índios, vinte uma povoações de Brancos e três povoações de Índios ${ }^{48}$. Entre as vilas de Brancos, estavam a Vila da Fortaleza, a Vila do Aquiraz, a Vila de Santa Cruz do Aracati, a Vila do Icó, a Vila Real do Sobral, a Vila Real da Granja e a Vila Real do Crato. As vilas de Índios eram a Vila Viçosa Real, a Vila Real do Soure (atual Caucaia), a Vila Real do Arronches (atual Parangaba), a Vila Real de Messejana e a Vila de Montemor o Novo d'America (atual Baturité). As povoações de Índios era a povoação de Montemor o velho (atual Guaiúba), a povoação de Amofala e a povoação de Bayapina (atual Ibiapina). As povoações de Brancos eram a povoação de Quixeramobim, o Arraial dos Cariris (atual Missão Velha), a povoação dos Inhamuns (atual Jucás), a povoação Serra dos Cocos (atual Guaraciaba), a povoação de Russas, a povoação de Telha (atual Iguatu), a povoação de Amontada, a povoação de Cascavel, a povoação de São João (atual São João do Jaguaribe), a povoação de Jaguaribe Mirim (atual Jaguaribe), a povoação de Mossoró, a povoação de São José do Aracati ${ }^{49}$, a povoação da Beruoca, a povoação de Cajuais ${ }^{50}$, a povoação da Serra da Uruburetama ${ }^{51}$, a povoação de Siupé, a povoação do Trairí, a povoação de Mata Fresca ${ }^{52}$, a povoação de Jiqui ${ }^{53}$ e o povoado de Catinga de Goes ${ }^{54}$.

Em 1817, a Carta Marítima e Geographica da Capitania do Ceará levantada pelo eng. Silva Paulet apresenta 16 vilas e 54 povoados interligados por estradas que cruzavam todo o Ceará (figura 02 ). Além das doze vilas enumeradas pelas noticias de 1783, mais quatro núcleos foram fundados como vilas no Ceará: a vila de Campo Maior (atual Quixeramobim), a vila de São Bernardo das Russas (atual Russas), a vila de São João do Príncipe (atual Tauá) e a vila de Jardim. Entre os povoados, estavam a povoação de Cascavel, de Monte-mór o velho, de Guaiúba, de Maranguape, de Siupé, dos Itans, de Canindé, de Santa Cruz, do Trairi, de São José, de São Bento d'Amontada, de Sta Quitéria, da Boa Vista $^{55}$, da Beruoca, de Santo Antonio, de São Benedito, de Ibuassu, de Baiapina, da Vila Nova d'El Rey, de Lapa ${ }^{56}$, de São Gonçalo, da Boa Viagem, de Santa Rita ${ }^{57}$, de Mombaça, de Quixadá, da Barra do Sitiá, do Livramento ${ }^{58}$, de São João, do Tabuleiro d'Areia, do Frade, de Santa Rosa, do Queixossó, de Santo Antonio, de Cosme e Damião, do Saco da Orelha, da Telha, do Poço do Mato, de S. Vicente das Lavras, de Umari, de São Mateus, das Flores, de Arneirós, de Cocossi, da Cruz, do Brejo Grande, da Barbalha, de Missão Velha, dos Milagres, de Santa Rosa, da Porteira, do Córrego do Ramalho ${ }^{59}$, da Catinga dos Goes, do Jiqui e da Montamba ${ }^{60}$. 

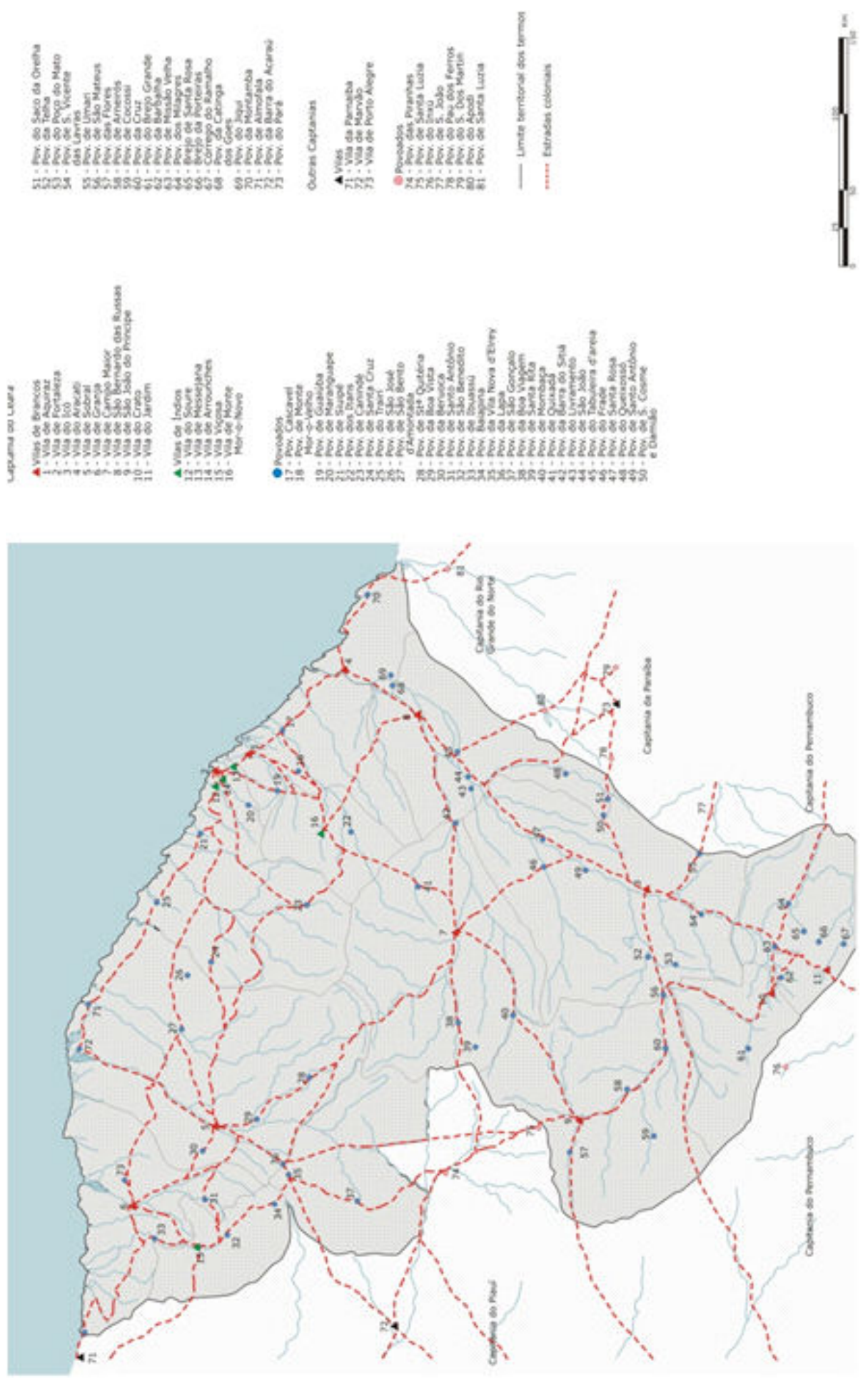

Figura 2. As estradas coloniais do Ceará - 1817. Fonte: Mapa elaborado pelo autor a partir das informações contidas na Carta / Marítima e Geográfica / da / Capitania do Ceará. / Levantada por ordem / do / Govor Manoel Ignácio de Sampayo / por seu ajudante d'ordens / Antonio Joze da Sa Paulet. 1817. Fonte: Gabinete de Estudos Arqueológicos de Engenharia Militar. Lisboa. Desenho No 4578. Armário 1A. Prateleira 10 A. Pasta 53. 


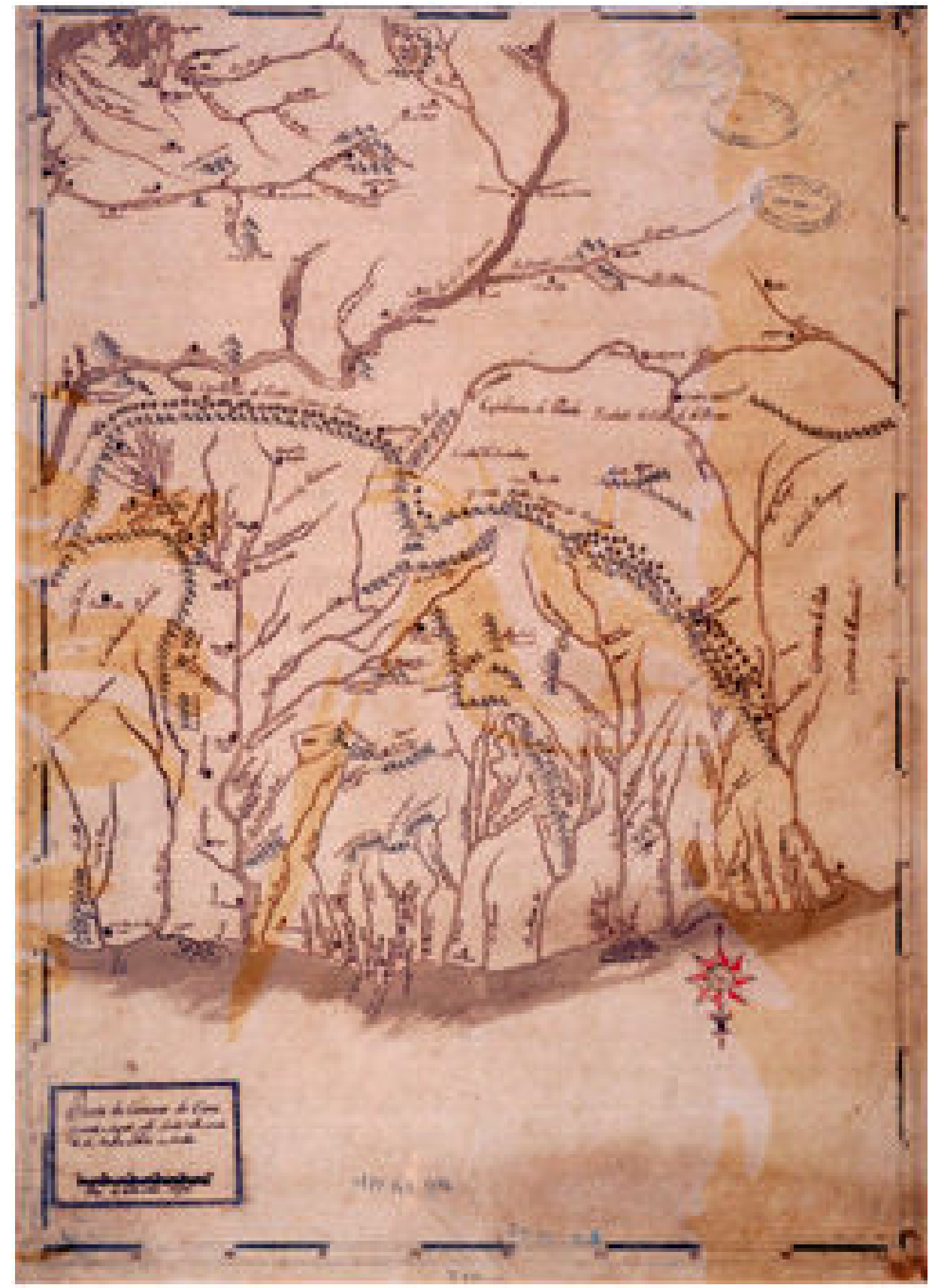

Fonte: Arquivo Histórico do Exército - Divisão de História - Mapoteca II - Localização 15.01.3124.

Figura 3 - Planta da Comarca do Ciará Grande e seguito pello sertão athe a cidade da Bahia de Todos os Santos. 


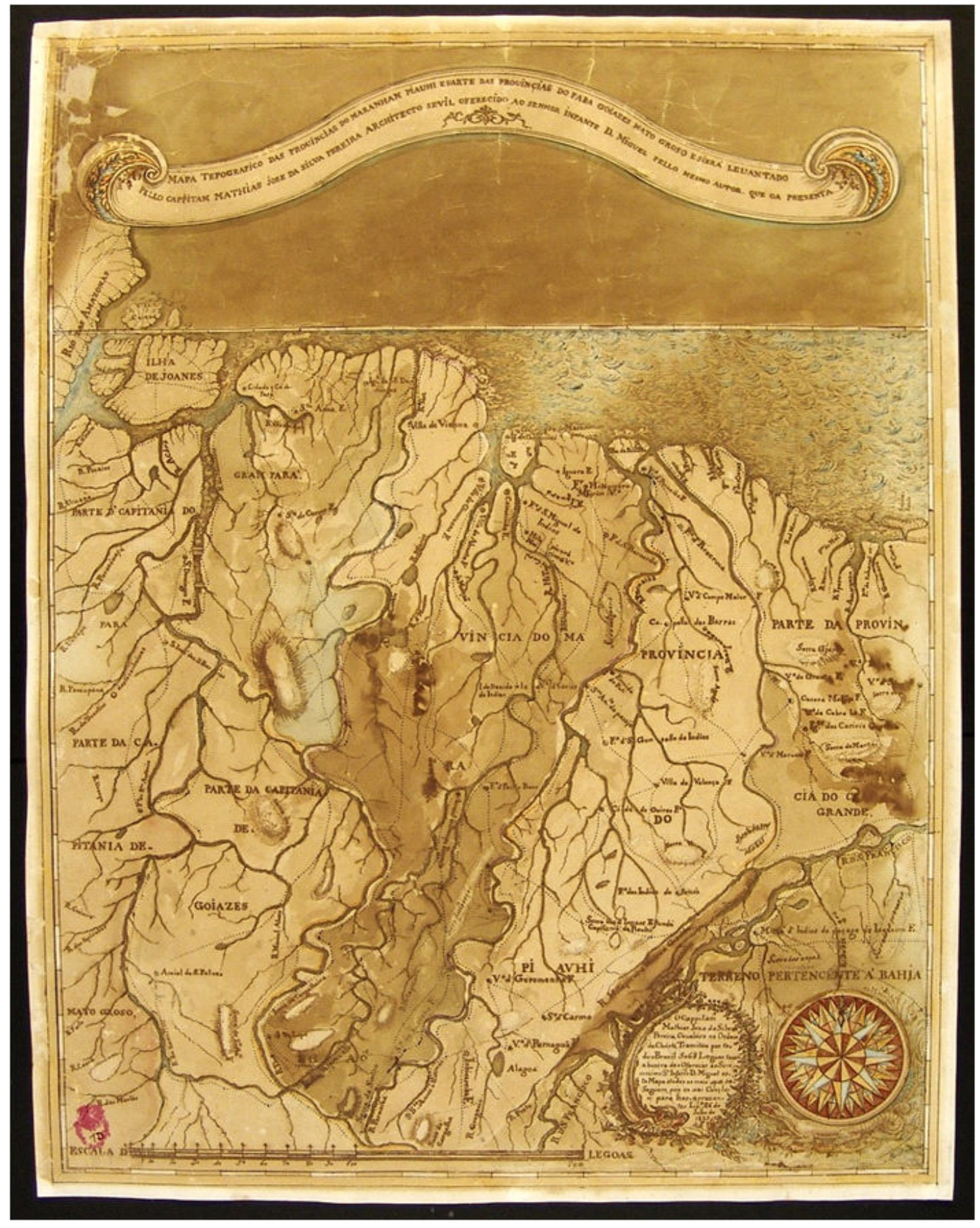

Figura 4 - Mapa topográfico das Provincias do Maranhão, Piauhi e parte das Provincias do Pará, Goiazes, Mato Grosso e Ceará, levantado pelo mesmo Capitão e oferecido ao Infante D. Miguel. Lisboa 26 de julho de 1823. Emoldurado, medindo 0,71X0,57S!. Biblioteca da Ajuda. Cota CART. MS. (ARM.BRANCO). 


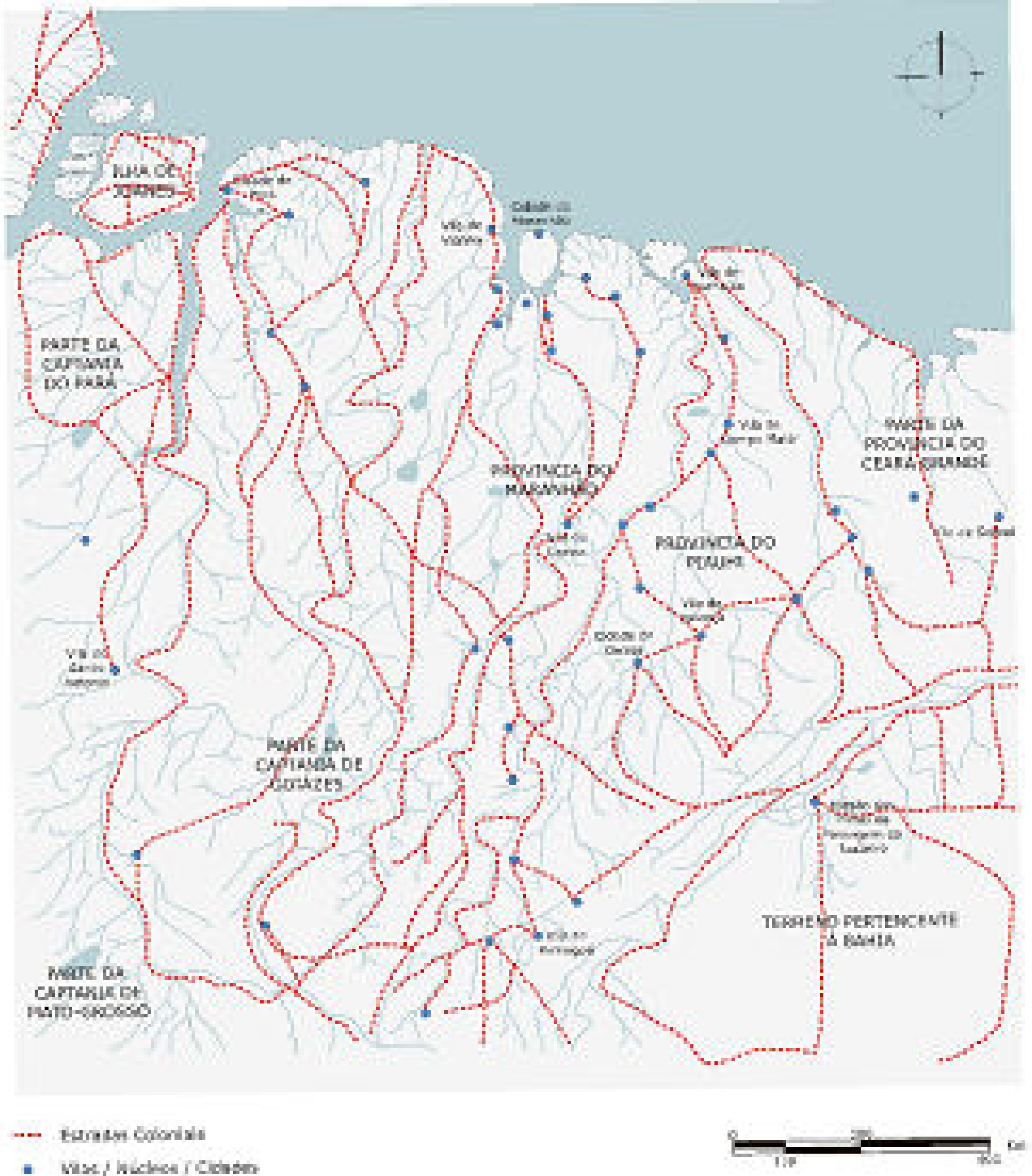

Figura 5 - Mapa esquemático elaborado pelo autor a partir do mapa topográfico das Províncias de Mranhão, Piauhi e parte das Províncias do Pará, Goiaze3s, Mato Grosso e Ceará, levantada pelo mesmo Capitão e oferecido ao Infante D. Miguel. Lisboa, 26 de julho de 1823. 
Analisando esta carta de 1817 e a Decripção Geográfica Abreviada da Capitania do Ceará, de 1816, do Engo. Antonio Jozé da Silva Paulet, sabemos que da vila de Aquiraz seguiam três estradas. Uma saía em direção a Fortaleza, outra em direção ao Aracati e a terceira seguia no rumo da vila de Campo Maior, subindo o rio Xoró e o Pirangi, passando pela vila de Monte-mór o Novo da América e pela povoação de Queixada.

De Fortaleza, saia a estrada geral - a Estrada Velha de Capistrano - à beira mar passando pela vila de Messejana, pela vila de Aquiraz, pelo povoado de Cascavel, pela vila do Aracati e pelo povoado de Montamba em direção às Capitanias do Rio Grande do Norte e Pernambuco. Saía também a estrada para vila do Soure, seguindo em direção a Sobral, Granja, Parnaíba e alcançando o Maranhão. Outra estrada seguia em direção ao Canindé; e mais uma em direção à vila de Monte-mór o Novo da América, passando pela povoação de Guaiúba. Uma última ligava a vila de Fortaleza à vila de Arronches.

Segundo a "Carta Geográfica do Ceará" - redigida a partir da carta manuscrita levantada em 1817 por Silva Paulet, com observações de Schwarzmann e de Martius - de Fortaleza partiam a "Estrada de Jacarecanga", a "Estrada de Soire", a "Estrada dos Arronches" com uma bifurcação para "Estrada das Olarias", a "Estrada do Aquiráz" com uma outra bifurcação para a Estrada da Precabura e uma última, a "Picada de Mocoripe". Estradas deram origem a duas importantes artérias de comunicação no espaço intra-urbano e as principais saídas da cidade atual (figura 6).

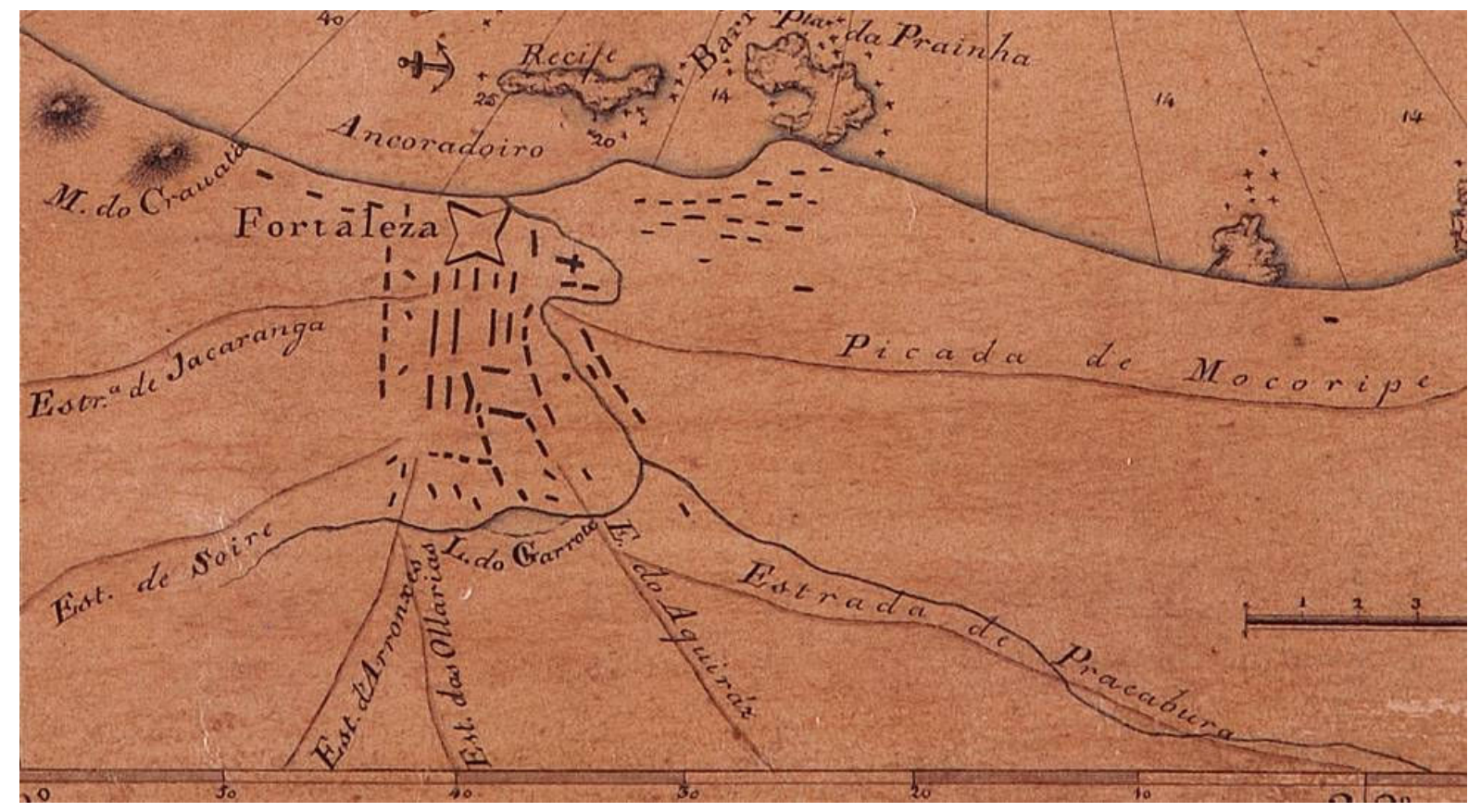

Figura 6. Detalhe da Carta Geográfica do Seara. Fonte: Arquivo Histórico do Exército - Divisão de História Mapoteca II - Localização: 02.04.337.

Por Aracati passava a estrada que vinha de Fortaleza em direção ao Rio Grande do Norte - a antiga Estrada Velha - e partia uma segunda em direção ao Icó - antiga Estrada Geral do Jaguaribe - passando pela vila das Russas, pela povoação de São João e de Santa Rosa. Já sabemos que o Icó acha-se no cruzamento da Estrada Geral do Jaguaribe e a Estrada das Boiadas. Do Icó, a primeira seguia na direção do Povoado de São Vicente das Lavras e do Povoado de Missão Velha, já no Cariri.

De Sobral, partiam duas estradas para Fortaleza. Uma, "larga e plana", seguia pelo norte da serra de Uruburetama passando pela povoação de S. Bento d'Amontada, e outra, cruzava a serra, atravessando o povoado da Cruz. Ambas se uniam nas proximidades do rio Curu, e seguiam para a vila do Soure e 
Fortaleza. Esta é a mesma que saía de Fortaleza passando pelo Soure em direção a Sobral. Outra estrada descia o rio Acaraú, alcançando o povoado da barra do Acaraú. Mais uma comunicava Sobral com a vila de Granja e em seguida com o Piauí. Para o Piauí, também se podia ir de Sobral pelas estradas que cruzavam a vila de Viçosa Real e a vila Nova d'El Rey. Esta Vila estava diretamente ligada à vila de Marvão na Capitania piauiense. Também de Sobral alcançava-se a Capitania de Pernambuco pelo interior, através de uma estrada "incomoda [...] e deshabitada" que passava pelo povoado de Boa Vista, de Santa Quitéria e pela vila de Campo Maior - Estrada Nova das Boiadas. Todas as demais vilas também se achavam conectadas pelas estradas cearenses.

A despeito, porém, de o território encontrar-se inteiramente interligado, o abastecimento da Capitania por uma produção interna de comestíveis era bastante rudimentar em decorrência das grandes distâncias entre as vilas. Este era caso das frutas produzidas nas proximidades do Crato, distante do Aracati "mais de 90 legoas" e na "Serra de Uruburetama, 30 legoas da villa de Fortaleza" (PAULET, 1898). Já a mandioca e legumes produzidos na Vila Viçosa Real não eram comercializados porque "não há pontos de consumo" (Ibidem). Por outro lado, ainda no início do século XIX, a maioria da população dedicava-se "à criação dos gados", não havendo uma atividade corrente da agricultura pelas próprias condições climáticas, à exceção eram as serras. O cultivo de hortaliças, mesmo no inverno ou em regiões serranas, era desconhecido. A falta era geral e "'só pelas margens do Jaguaribe até o Icó há algumas plantações de melancias, melões e abóboras, nos lugares que o rio alaga e deixa nateiros chamados vazantes", afirma Paulet (Ibidem). Nem mesmo a produção açucareira da região do Cariri era suficiente para abastecer a Capitania, que se valia da produção pernambucana.

Este era o quadro da rede urbana cearense no início do século XIX. Dezesseis vilas fundadas - a maioria delas "arruinadas" - e 54 povoações. Embora o Ceará estivesse totalmente interligado e ligado a outras capitanias por estradas carroçáveis, não significava a existência de uma rede de abastecimento interno de produtos locais, exceto os derivados da pecuária sertaneja e cada vez mais o algodão, que deu sentido econômico para a futura Província por todo o oitocentos.

\section{Notas}

\footnotetext{
${ }^{1}$ Este artigo é parte da Tese de Doutoramento - A Urbanização do Ceará Setecentista. As Vilas de Nossa Senhora da Expectação do Icó e de Santa Cruz do Aracati - defendida no Programa de Pós-Graduação em Arquitetura e Urbanismo, no ano de 2007, na Universidade Federal da Bahia.
}

\footnotetext{
${ }^{2}$ Para Moraes (2000, p.264), é exatamente no "apetite territorial de certas sociedades européias", onde se deve buscar o "móvel primeiro da expansão marítima efetuada no "longo" século XVI". A avaliação do êxito ou do fracasso da conquista está diretamente relacionada à "capacidade plástica" da Coroa de se "apropriar de lugares os mais diversos e moldá-los segundo seus interesses".

${ }^{3}$ Ver Cortesão (1984).

${ }^{4}$ Ainda segundo Moraes (2000, p.265), "qualquer colônia é o resultado de uma conquista territorial". Um "espaço novo na perspectiva do colonizador". Consideramos, neste sentido, que qualquer espaço da Colônia ainda não plenamente ocupado caracterizava-se, também, como um espaço a ser conquistado.

${ }^{5}$ Barrios (1986, p.6-8) considera as praticas políticas "como as ações sociais que têm por finalidade a conquista ou a detenção do poder". Elas sempre envolvem o "estabelecimento de uma relação de dominação, caracterizando o nexo homem/homem, que se expressa numa relação de apropriação, característica do nexo sociedade/espaço físico".

${ }^{6}$ Aqui tomamos as "etapas dos processos de colonização" propostas por Moraes (2000, p. 276-279), para entender como a Coroa instala-se na capitania cearense. O autor afirma que a seqüência "- descoberta - exploração, conquista - instalação, consolidação - expansão, complexização - manifesta-se de forma recorrente nas áreas onde se instala o processo colonizador”, sendo observável em "diferentes épocas conforme os espaços enfocados do continente americano". Afirma ainda que não se trata de uma cronologia. A "instalação" "tratava-se de uma etapa inicial de submissão das populações locais e de apropriação dos lugares, envolvendo a pioneira edificação dos assentamentos europeus na América. Na etapa de "consolidação" percebe-se a "plena montagem das estruturas produtivas , implicando já a instalação de equipamentos e razoável dispêndio de trabalho morto na colônia". Ela fez-se "geralmente acompanhar de alterações na estrutura fundiária, no estatuto jurídico das propriedades, e ainda na organização do mercado de terras e de trabalho".
} 
${ }^{7}$ A lógica da valorização espacial nas formações latino-americanas é minuciosamente posta por Moraes (2000, p. 282), procurando as bases da formação territorial no Brasil. O autor afirma que "havendo conquista, a dimensão espacial vem ao centro da estruturação da vida econômica e social, tornando-se uma determinação histórica". Após o povoamento, a fixação no território significou a "instalação de equipamentos, a fixação de valor". Tudo respondendo à lógica da conquista, "até o momento em que o volume do capital internalizado começa a gerar interesses locais, que se podem antagonizar ou não com os da metrópole, ao sabor das conjunturas".

${ }^{8}$ Após a restauração, Rossa (2000, p.289) acentua que a criação das vilas e cidades - essenciais "para a afirmação da soberania portuguesa" - passou a ser "prerrogativas exclusivas do Estado através de Cartas Régias aos Governadores". Araújo (1998, p.25) reconhece como o primeiro paradigma do urbanismo da expansão portuguesa a presença da fortificação. O segundo, associado ao primeiro, faz "referência à presença tutelar do Estado na formação urbana de seus territórios", pois em nenhum momento da expansão, o urbanismo esteve desligado da acepção central da Coroa.

9 Para Moraes (2000, p.265) a "formação colonial expressa, já em sua gênese, uma qualidade de subordinação". O autor reconhece a conquista "como relação específica entre uma sociedade que se expande e as pessoas, recursos e áreas dos lugares onde se exercita esta expansão". E a subordinação como o "resultado de uma ação que lhe é externa motivada pelos anseios sociais que tem origem em outro lugar".

${ }^{10}$ Puntoni (2002, p. 285-286) observa que "ao fim e ao cabo" da conquista, "tanto os negros dos Palmares como os Tapuias irredentos" dos sertões nordestinos "foram incapazes de se opor às forças luso-brasileiras, muito mais poderosas, não apenas tecnologicamente e estrategicamente, mas porque tinham atrás de si um sistema social cuja complexidade e integração tornava inexeqüível a resistência, fosse ela interna ou externa, em razão de sua fragmentação ou dissociação. Os tapuias que sobreviveram ao extermínio, submetiam-se a uma dominação deletéria dentro dos limites dos aldeamentos, espécie de prisão cuja gravidade aumentava proporcionalmente à violência dos sertões".

${ }^{11}$ Em comparação com a zona do açúcar, o baixo nível econômico e o pequeno índice de produtividade da atividade criatória são avaliados por Prado Junior (1985, p.44) como decorrência direta das particularidades do interior nordestino, onde se alia uma baixa pluviosidade com uma grande irregularidade das precipitações à predominância da vegetação hidrófilas, basicamente cactáceas e ainda, uma baixa densidade demográfica. No sertão, a chuva quando ocorre se concentra em dois ou três meses anuais, não sendo raros os anos seguidos de estiagem prolongada. Como conseqüência do quadro pluviométrico, os rios alternam longas temporadas de ausência total de água com curtos períodos de abundância, muitas das vezes destruidores em sua violência. O resultado foi um território de um milhão de quilômetros quadrados ocupado por um rebanho que não chegou a alcançar dois milhões de cabeças de gado; ou seja, apenas duas cabeças em média por quilômetro. Ainda como conseqüência do quadro fisiográfico da região, era ínfima a qualidade da produção, pois as reses não forneciam mais de 120 quilos de carne, de pouco valor, por animal.

${ }^{12}$ Em 1775, a população arrolada na Capitania foi de 34.000 habitantes (ARARIPE, 2002, p.93). De acordo com o Mappa do total de todos os habitantes compreendidos nas quatro capitanias deste Governo de Pernambuco, extrahido das relações dos Parochos em o anno de 1782, presente na Idéia da População da Capitania de Pernambuco, e das suas annexas (1923, p. 110) a Capitania de Pernambuco possuía 229.743 habitantes; a do Ceará 61.408 habitantes; a da Paraíba 52.468 habitantes e a do Rio Grande do Norte 23.812 habitantes.

${ }^{13}$ Ver Girão (1962, p.121; 1983; 1985, p.147 a 149; 2000, p.133 a 146) e Nobre (1977).

${ }^{14}$ Segundo Braga (1947, p.151), “as oficinas não tardaram a atrair as boiadas do sertão. Trazendo-as a marinha, os fazendeiros evitavam os percalços das grandes caminhadas e ganhavam o imposto de 400 reis por boi e 320 réis por vaca chamado subsídio do sangue cobrado sobre o gado abatido que não era de desprezar numa matança de milhares de cabeças e quando a arroba de carne fresca se vendia a 240 réis. As boiadas que se deslocavam para as feiras pernambucanas e baianas começaram a rumar em direção a foz das suas próprias ribeiras. Este movimento local, marinha e sertão interpenetraram-se comercialmente e os laços administrativos entre as duas tornaram-se mais efectivas".

${ }^{15}$ Esta ordem régia encontra-se transcrita no Estudo do Remanejamento da Pecuária na Zona Norte do Ceará de Luciara Aragão (1986, p. XXVIII).

${ }^{16}$ Ofício do [governador da capitania de Pernambuco], Luis Diogo da Silva, ao [secretário de Estado do Reino e Mercês], Sebastião José de Carvalho e Melo, sobre o requerimento dos homens de negócios daquela praça, em que pedem a criação de uma Companhia para resgatar as carnes secas e couros do sertão. Anexos: 7 docs. Projeto Resgate. Documentos Manuscritos avulsos da Capitania de Pernambuco. AHU_ACL_CU_015, Cx. 015, D. 6965. Sobre a Companhia de Comércio ver RIBEIRO JUNIOR (2004).

${ }^{17}$ Carta do Ouvidor do Ceará, Manuel Magalhães de Pinto Avelar, à rainha [D. Maria I], sobre a situação econômica da referida Capitania. Quixeramobim, 3 de fevereiro de 1787. Projeto Resgate. Documentos manuscritos avulsos da Capitania do Ceará. (1618 - 1822). AHU_ACL_CU_017.Cx. 17. D. 644. Dos núcleos citados pelo Ouvidor, hoje também é reconhecida a importância da atividade criatória na estruturação da vila do Icó.

${ }^{18}$ Analisando a constituição das frotas de açúcar e do ouro na América Portuguesa, Godinho (1990, p.489) reconhece a importância do couro. Afirma que ele "representa um papel muito importante no Atlântico do século XVIII e o seu volume, se não o seu valor, é comparável ao do açúcar. É necessário não o perder de vista; dá-se um enorme desenvolvimento da criação de gado nas regiões de Buenos Aires [...] Ao mesmo tempo desenvolvem-se as regiões setentrionais do Brasil: as frotas provenientes do Norte brasileiro são, até certo ponto, frotas de coiro".

${ }^{19} 1778$ [Lisboa]. Mapa geral dos efeitos que vieram das capitanias de Pernambuco e Paraíba para Lisboa e cidade do Porto, desde 
o estabelecimento da Companhia Geral de Pernambuco e Paraíba até o ano de 1778. Projeto Resgate. Documentos manuscritos avulsos da capitania de Pernambuco. (1590 - 1825). AHU_ACL_CU_015, Cx. 132, D.9924.

${ }^{20}$ Total de caixas de açúcar, couro em cabelo, atanados, meios de sola entre 1760 e 1776. Fonte: 1778, [Lisboa]. "Mapa geral dos efeitos que vieram das capitanias de Pernambuco e Paraíba para Lisboa e cidade do Porto, desde o estabelecimento da Companhia Geral de Pernambuco e Paraíba até o ano de 1778". Projeto Resgate. Documentos manuscritos avulsos da capitania de Pernambuco. AHU_ACL_CU_015, Cx. 132, D. 9924.

${ }^{21}$ Lista do Cálculo de exportação das Capitanias de Pernambuco e Paraíba para o reino no ano de 1778. Projeto Resgate. Documentos manuscritos avulsos da capitania de Pernambuco. $(1590-1825)$. AHU_ACL_CU_015, Cx. 132, D. 9926 e AHU_ACL_CU_015, Cx. 132, D. 9927.

${ }^{22}$ Cálculo do que produziu as exportações de açúcar branco, açúcar mascavo, couros em cabelo, atanados, meios de sola e vaquetas provenientes de Pernambuco e Paraíba para Portugal em 1778 Fonte: 1778 [Lisboa]. Lista do cálculo da exportação das capitanias de Pernambuco e Paraíba para o reino no ano de 1778. Projeto Resgate. Documentos manuscritos avulsos da capitania de Pernambuco. AHU_ACL_CU_015_Cx 132, D. 9927.

${ }^{23}$ Livro de Registro de provisões, alvarás, cartas régias e ofícios do Conselho Ultramarino para os governadores e mais entidades das Capitanias de Pernambuco, Paraíba e Ceará. 1 vol. 400x280, c. 245 fls. Projeto Resgate. Documentos Manuscritos Códices I (1548 - 1821). AHU_ACL_CU- Códice 262. P. 56 e 56v.

${ }^{24}$ Girão (2000, p.104) lembra que a arrecadação anual do imposto das carnes se dava pela arrematação dos contratos; e que nem sempre elas ocorriam por conta das secas. Ainda segundo o autor, a contribuição decorrente destes contratos era de 200 rs por rês abatida e mais 32 rs, relativos ao subsídio literário, também pago à Fazenda Real. Por fim, acrescenta um outro dado. Afirma que nos “tempos normais, e enquanto o valor do boi variava na base de $1 \$ 600$, no máximo $2 \$ 000$, o negócio oferecia lucro compensador e apareciam os lançadores. Porém mais para a segunda metade do século, com a alta do valor do boi, que chegou a duplicar em virtude do comércio de exportação das carnes secas, sem um correlativo aumento do preço de venda da carne fresca nos açougues das Câmaras, os arrematadores, temendo prejuízos, rareavam". Segundo Abreu (1997, p.211), a opção da Coroa pelo sistema de contratação resultou da impossibilidade de um controle direto sobre tudo o que era produzido. O serviço de cobrança de cada capitania era posto em arrematação, periodicamente, sendo o contrato entregue a quem oferecesse mais. A Coroa "delegava ao arrematante (também conhecido como dizimeiro ou contratador dos dízimos reais) o poder de cobrar o tributo dos produtores diretos, que podiam pagá-lo em espécie ou em dinheiro de contado".

${ }^{25}$ Livro de Registro de provisões, alvarás, cartas régias e ofícios do Conselho Ultramarino para os governadores e mais entidades das Capitanias de Pernambuco, Paraíba e Ceará. 1 vol. 400x280, c. 245 fls. Projeto Resgate. Documentos Manuscritos Códices I (1548-1821). AHU_ACL_CU- Códice 262. P. 56 e 56v.

${ }^{26}$ Acréscimos que houve no rendimento da Coroa pelos dízimos cobrados na capitania de Pernambuco e suas anexas entre 1774 e 1788. Fonte: Idéia da população da capitania de Pernambuco, e das suas annexas (1923. P. 98).

${ }^{27}$ Ver contribuição da capitania do Ceará para o cofre da Coroa entre 1774 e 1778. Fonte: Ibidem. P. 95/96.

${ }^{28}$ Arquivo da Torre do Tombo. Capitania do Ceará Grande. Gerardo Marques da Costa que serviu de Almoxarife na capitania do Ceará com a Real Fazenda, pelo que recebeu e despendeu em todo o anno de 1777 - Livro 206; Gerardo Marques da Costa que serviu de Almoxarife na capitania do Ceará com a Real Fazenda, pelo que recebeu e despendeu em todo o anno de 1778 - Livro 207; Gerardo Marques da Costa que serviu de Almoxarife na capitania do Ceará com a Real Fazenda, pelo que recebeu e despendeu em todo o anno de 1779 - Livro 208, Diogo Rodrigues Correa que serviu de Almoxarife na capitania do Ceará com a Real Fazenda, pelo que recebeu e despendeu em todo o anno de 1782 - Livro 210; Pedro Barrozo de Souza, que sérvio de Almoxarife na Capitania do Ceará com a Real Fazenda, pelo que recebeu, despendeu em todo o anno de 1783 - Livro 211; Pedro Barrozo de Souza, que sérvio de Almoxarife na Capitania do Ceará com a Real Fazenda, pelo que recebeu, despendeu em todo o anno de 1784 - Livro 212 e Pedro Barrozo de Souza, que sérvio de Almoxarife na Capitania do Ceará com a Real Fazenda, pelo que recebeu, despendeu em todo o anno de 1784 - Livro 213.

${ }^{29}$ Arrecadações da capitania cearense para os anos de 1777 a 1778, 1782, 1783 a 1785. Ibidem.

${ }^{30}$ Ordem Régia de 13 de fevereiro de 1699 mandando criar vila na capitania do Ceará (STUDART, 2001a, p.114).

${ }^{31}$ Estas mesmas justificativas - juntamente com os problemas das grandes distâncias, "a inacessibilidade e o isolamento decorrentes da ausência de uma rede de transporte" - foram utilizadas para a criação de vilas e sedes de comarcas em Portugal por todo o século XVIII. Quanto aos representantes do Estado o "problema residia na ignorânçia dos magistrados e dos ofíciais locais, nomeadamente na dos juizes ordinários das terras, incapazes de bem administrar a justiça e de promover a observância das leis" (SILVA, 1998, p. 40-41).

${ }^{32}$ Há uma transcrição da Carta Regia de fundação do Icó na Carta do ouvidor do Ceará, José da Costa Dias e Barros, à rainha (D. Maria I) apontando as causas da desordem na capitania e pedindo aprovação das fintas que estabeleceu. 1779, Junho, 25, Aquiraz. In: Projeto Resgate. Documentos manuscritos avulsos da Capitania do Ceará (1618 - 1832). AHU_ACL_CU_017.Cx.9 D.564. Ver Barroso (1962, p. 124) e Santos (1968, p.44).

${ }^{33}$ CONSULTAS acerca de vários assuntos respeitantes à capitania de Pernambuco - 1712-1749. Projeto Resgate. Documentos Manuscritos Códices I (1548-1821). AHU_ACL_CU- Cód.266. P.208 e 208v.

${ }^{34}$ Ibidem. 
${ }^{35}$ 1746, dezembro, 12. CONSULTA do Conselho Ultramarino [D. João V], sobre a necessidade de se criar uma nova vila em Aracati de Jaguaribe. Anexo: cópias de cartas e provisões. Projeto Resgate. Documentos manuscritos avulsos da Capitania do Ceará (1618-1832).AHU_ACL_CU_017, Cx. 5, Doc. 304.

${ }^{36}$ Sobre o Marques de Pombal, Ministro e Secretário dos Negócios de Estado dos Negócios do Reino, no reinado de D. José I, ver Maxwell (1996) e Serrão (1987).

${ }^{37}$ Antes de se ocupar com a estratégia pombalina de criação das vilas nas Capitanias de São Paulo, Porto Seguro e da Bahia, Flexor (1996, p. 602) enumera uma série de ações que compuseram o programa de "reorganização econômica, social, administrativa, judicial e, sobretudo política" na América Portuguesa. Segundo a autora, foram feitos levantamentos cartográficos, criaram-se as "comissões de limites", criou-se o "Tribunal da Relação do Rio de Janeiro", foram organizadas quatro "capitanias subalternas ao Grão-Pará e Maranhão", foi dada a "Lei de liberdade de comércio e de bens individuais aos índios", obrigou-se que os nomes bárbaros das aldeias fossem substituídos por outros das vilas "civilizadas", colocou-se os "índios na administração municipal, implantou-se a língua portuguesa como obrigatória, criou-se a Companhia de Geral do Grão Pará e Maranhão, a Companhia Geral de Pernambuco e Paraíba, caminhos foram abertos para a intensificação do comércio entre as capitanias, foi estabelecido o comercio direto entre Portugal e diversos portos no Brasil, estabeleceu-se o "Directorio dos índios do Grão Pará e Maranhão", dentre outras medidas.

${ }^{38}$ Atual Caucaia.

${ }^{39}$ Atual Parangaba.

${ }^{40}$ Esta lei encontra-se transcrita nos Registros dos Autos da erecção da real vila de Monte-mór o Novo da América (1891).

${ }^{41}$ As Leis de 6 e 7 de junho de 1755 e o Alvará de 8 de maio de 1758 também acham-se nos Registros dos Autos da erecção da real vila de Monte-mór o Novo da América (Ibidem).

${ }^{42}$ De acordo com Flexor (2004, p.205), a liberdade dos índios era fictícia, pois eles estavam sujeitos às determinações do "Directório que se deve observar nas povoaçoens dos Índios do Pará, e Maranhão enquanto sua Magestade não mandar o contrário", de 1758. O Diretório está incluso nas atas de ereção da missão da Palma à condição de vila de Montemor-o-Novo d'América. (Villa de Monte-mór o Novo da América, 1884). Ver ainda Beozzo (1983).

${ }^{43}$ A Ordem Régia encontra-se transcrita nos Autos de elevação da Vila de Quixeramobim (OLIVEIRA, 1890, p.281 a 283). Para Lemenhe (1991, p.36), as queixas dos administradores locais contra os chamados "vadios" assumem nos sertões da pecuária maiores proporções; pois "apesar de muitos potentados necessitarem de homens para compor exércitos particulares e muita terra potencialmente cultivável" pouco ou nada sobrava para os "qualificados de "vadios": mestiços, índios aculturados; homens sem terra e sem trabalho". Eles eram inconvenientes porque subvertiam a "ordem que, no caso consistia nas agressões contra os bens gado e meios de subsistência - e vida dos potentados e seus agregados". Daí a preocupação reinante em "construir presídios ou de reforçar os poucos existentes".

${ }^{44}$ Edital de convocação para a solenidade de criação da vila (OLIVEIRA, 1890, p.278-280).

${ }^{45}$ Crateús (Antiga vila Príncipe Imperial) pertencia ao Piauí sendo incorporado ao território cearense com o Decreto Geral $\mathrm{n}^{\circ}$ (3012 de 22 de outubro de 1889). Ver Girão e Martins Filho (1939, p.147).

${ }^{46}$ Antiga Vila da Mocha no Piauí.

47 Carta do ouvidor do Ceará, Manuel Magalhães Pinto Avelar, à Rainha (D. Maria I), sobre a situação econômica da referida capitania. 3 de fevereiro de 1787. Quixeramobim. Projeto Resgate - Documentos Manuscritos avulsos da Capitania do Ceará (1618-1832). AHU_ACL_CU_017,Cx. 11, Doc. 644. Ver anexo 7.

${ }^{48}$ Sobre os antigos e os atuais nomes das povoações ver Alencar, 1939; Girão e Martins Filho, 1939; Braga, 1964 e Girão, 1983 ;

${ }^{49}$ Hoje há um sítio chamado São José nos arredores do Aracati.

${ }^{50}$ Localidade de praia localizada no atual muncípio de Icapuí.

${ }^{51}$ Denominação genérica, impossível de ser identificada porque não apresenta o orago da matriz. Pode referir-se a Uruburetama, Itapajé, Itapipoca ou alguma outra localidade. Referia-se provavelmente a Uruburetama (São Francisco).

${ }^{52}$ Localidade hoje pertencente ao Município de Icapuí.

${ }^{53}$ Localidade no Município de Jaguaruana, a $30 \mathrm{~km}$ do Aracati.

${ }^{54}$ Atual Jaguaruana. Chamou-se União.

${ }^{55}$ Há várias localidades com o nome de Boa Vista no Dicionário de Alencar (1939). Não há, porém, nenhuma localidade com este nome perto de Sobral. Pode ser Trapiá ou Forquilha.

${ }^{56}$ Segundo Alencar (1939, p. 222), era uma "Povoação ao pé da Serra da Ibiapaba, onde há uma capella filial à freguesia de São Benedito". No mapa atual pode ser Graça ou Mucambo.

${ }^{57}$ No mapa atual é povoado no município de Mombaça, perto de Pedra Branca.

${ }^{58}$ De acordo com Alencar (1939, p. 229), "Povoação no Termo de Morada Nova, sobre o Riacho Livramento, com capella". O 
Riacho “nasce na freguesia do Riacho do Sangue e se lança no Jaguaribe, pela margem esquerda, na freguesia de Russas". No mapa atual é Uiraponga, perto de Jaguaribara.

${ }^{59}$ Nada foi encontrado nem em obras de referência bem no mapa atual.

${ }^{60}$ Segundo Alencar (1939, p.263), "Mutamba” é uma povoação a 70km do Aracati.

\section{Referência Bibliográfica}

ABREU, Maurício de Almeida. A apropriação do território no Brasil colonial. IN: CASTRO, Iná Elias de; GOMES, Paulo César da Costa; CORRÊA, Roberto Lobato (Org.). Explorações geográficas: percursos no fim do Século - Rio de Janeiro: Bertrand Brasil, 1997.

ALENCAR, Álvaro Gurgel de. Diccionário Geográfico Histórico e Descriptivo do Estado do Ceará. $2^{\circ}$ ed. Tipografia Minerva. Assis Bezerra \& Cia. Fortaleza. Ceará. 1939.

ANTONIL, André João. Cultura e opulência do Brasil por suas drogas e minas. (Separata do Boletim Geográfico, $n^{\circ} 166$ a 171). Com anotações de Orlando Valverde. Edição da Divisão Cultural. Rio de Janeiro. IBGE. Conselho Nacional de Geografia, 1963.

ARAGÃO, Luciara. Estudo do Remanejamento da Pecuária na Zona Norte do Ceará. $1^{\circ}$ e $2^{\circ}$ volume. Superintendência do Desenvolvimento do Estado do Ceará, Universidade Vale do Acaraú. 1986.

ARARIPE, Tristão de Alencar. História da Província do Ceará: desde os tempos primitivos até 1850. (Coleção Clássicos Cearenses; 5). Fortaleza: Edições Fundação Demócrito Rocha. 2002.

ARAÚJO, Renata Malcher de. As Cidades da Amazônia no século XVIII: Belém, Macapá e Mazagão. Série I. Ensaio 3. Porto. Faup. Publicações. 1998.

BARRIOS, Sonia. A produção do espaço. In: SOUZA, Maria Adélia. de; SANTOS, Milton. (Org.). A construção do espaço. São Paulo: Nobel, 1986.

BEOZZO, José Oscar. Leis e Regimentos das Missões. Política Indigenista do Brasil. Coleção "Missão Aberta"- VI. Centro Indigenista Missionário. São Paulo. Edições Loyola. 1983.

BRAGA, Renato. Um capítulo esquecido da economia pastoril do Nordeste. Revista do Instituto do Ceará. Fortaleza - Ce, Ed. Instituto do Ceará, Ltda.Tomo LXI, Ano LXI, 1947.

BRAGA, Renato. Dicionário Geográfico e Histórico do Ceará. Fortaleza. Imprensa Universitária, 1964. CASTRO, José Liberal de. A Fortaleza de Nossa Senhora da Assumpção da Capitania do Ceará Grande. Pleito de Tombamento. Formulada ao IPHAN. 2005. Não publicado.

CORTESÃO, Jaime. Alexandre de Gusmão e o Tratado de Madrid. 4v. Lisboa: Livros Horizonte. 1984. FLEXOR, Maria Helena Ochi. Núcleos urbanos criados por Pombal no Brasil do século XVIII. Anais do IV Seminário de História da Cidade e do Urbanismo. Rio de Janeiro: UFRJ/PROURB, 1996.

FLEXOR, Maria Helena Ochi. A rede urbana brasileira setecentista. A afirmação da vila regular. In: TEIXEIRA, Manuel (Org.). A Construção da Cidade Brasileira. Lisboa, Portugal, Livros Horizonte. 2004.

GIRÃO, Raimundo. Pequena História do Ceará. 2aed. Editora “Instituto do Ceará”, 1962.

GIRÃO, Raimundo. Os Municípios cearenses e seus distritos. Fortaleza, SUDEC, 1983.

GIRÃO, Raimundo. Evolução histórica cearense. Documentos do Nordeste 5. Fortaleza, BNB. ETENE, 1985 ,

GIRÃO, Raimundo. História Econômica do Ceará. $2^{\mathrm{a}}$ ed. Fortaleza, UFC, Casa José de Alencar, Programa Editorial, 2000.

GIRÃO, Raimundo e MARTINS FILHO, Antonio. O Ceará. Fortaleza. Ceará. Editora Fortaleza. 1939.

GODINHO, Vitorino Magalhães. As frotas do açúcar e as frotas do ouro. 1670-1770. IN: Mito e Mercadoria, Utopia e Prática de Navegação. Séculos XIII-XVIII. Lisboa. Difel. 1990.

IDÉIA DA POPULAÇÃO DA CAPITANIA DE PERNAMBUCO, E DAS SUAS ANNEXAS, extensão de suas costas, rios, e povoações notáveis, agricultura, numero de engenhos, contractos, e rendimentos reais, augmento que estess tem tido desde o anno de 1774 em que tomou posse do governo das mesmas capitanias 
o Governador e capitam General Jozé Cezar de Menezes. BNRJ. Annaes da Bibliotheca Nacional do Rio de Janeiro. 1918. Volume XL. Rio de Janeiro. Officinas Gráficas da Bibliotheca Nacional. 1923.

LEMENHE, Maria Auxiliadora. As Razões de uma cidade: conflito de hegemonias. Fortaleza: Stylus Comunicações, 1991.

MAXWELL, Kenneth. Marques de Pombal: paradoxo do Iluminismo. Trad. Antonio de Pádua. - Rio de janeiro: Paz e Terra, 1996.

MORAES, Antonio Carlos Robert. Bases da Formação Territorial do Brasil: o território colonial brasileiro no "longo" século XVI. (Estudos Históricos; 41). São Paulo: Hucitec, 2000.

MOTA, Aroldo. Município de Tauá: Origem. Revista do Instituto do Ceará. Tomo CXV, ANO CXV,

Trabalho enviado em novembro de 2008

Trabalho aceito em agosto de 2009 